\title{
Anorden
}

\section{Nordic Climate Policy}

A Case Study on Efficient Policy Measures

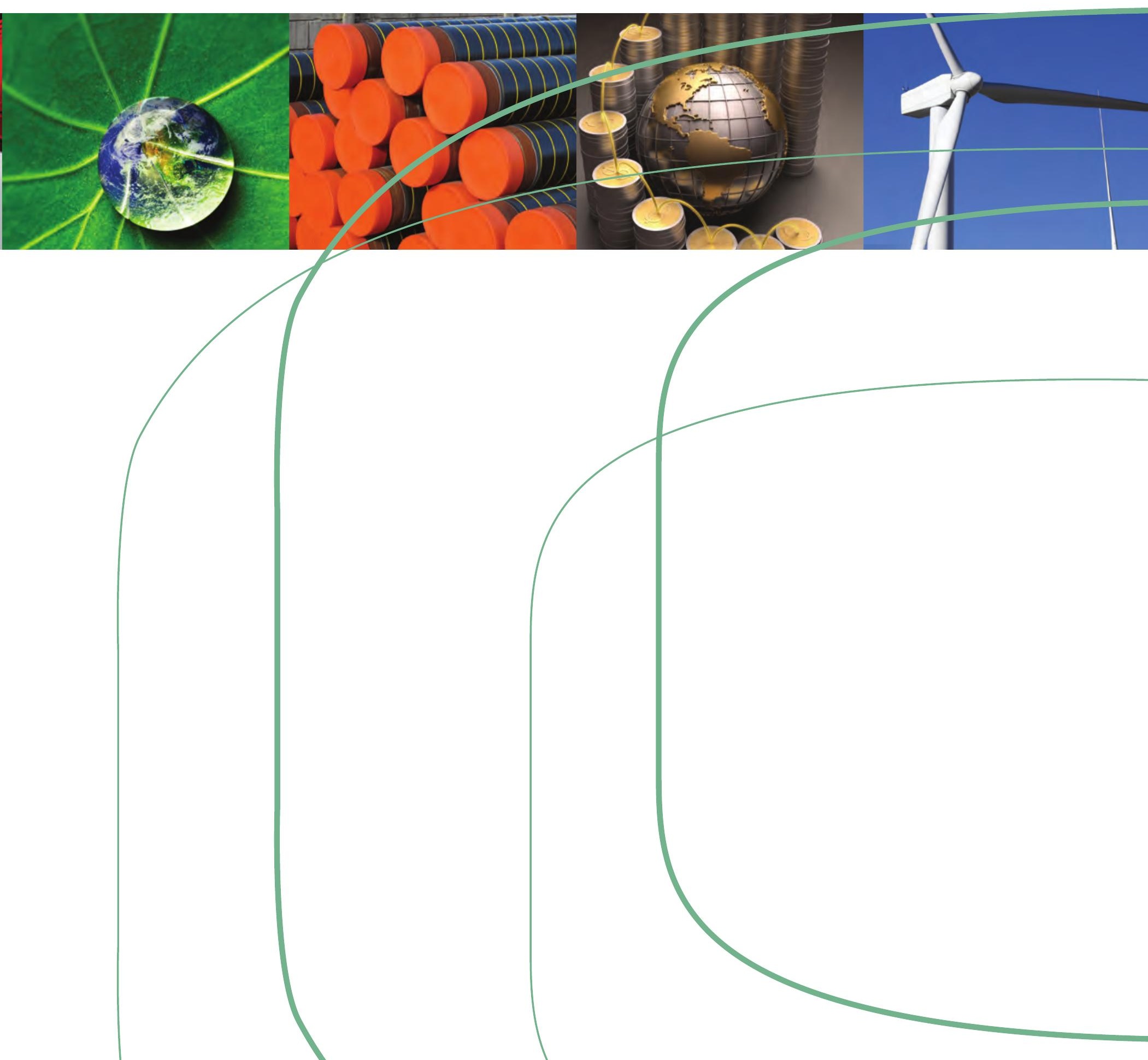



4 norden 



\section{Nordic Climate Policy}

A Case Study on Efficient Policy Measures 
Nordic Climate Policy

A Case Study on Efficient Policy Measures

ISBN 978-92-893-2755-8

ISBN 978-92-893-2756-5 (EPUB)

http://dx.doi.org/10.6027/TN2014-522

TemaNord 2014:522

ISSN 0908-6692

(C) Nordic Council of Ministers 2014

Layout: Hanne Lebech

Cover photo: SignElements

This publication has been published with financial support by the Nordic Council of Ministers. However, the contents of this publication do not necessarily reflect the views, policies or recommendations of the Nordic Council of Ministers.

www.norden.org/en/publications

\section{Nordic co-operation}

Nordic co-operation is one of the world's most extensive forms of regional collaboration, involving Denmark, Finland, Iceland, Norway, Sweden, and the Faroe Islands, Greenland, and Åland.

Nordic co-operation has firm traditions in politics, the economy, and culture. It plays an important role in European and international collaboration, and aims at creating a strong Nordic community in a strong Europe.

Nordic co-operation seeks to safeguard Nordic and regional interests and principles in the global community. Common Nordic values help the region solidify its position as one of the world's most innovative and competitive.

\section{Nordic Council of Ministers}

Ved Stranden 18

DK-1061 Copenhagen K

Phone (+45) 33960200

www.norden.org 


\section{Content}

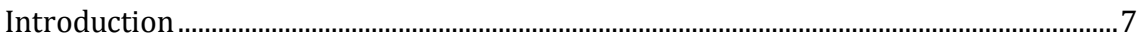

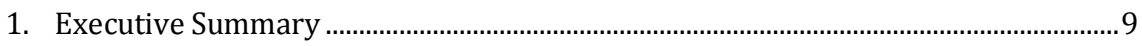

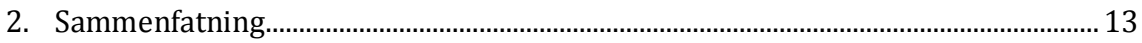

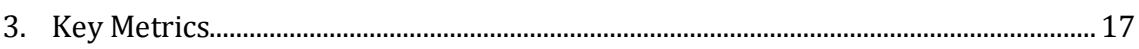

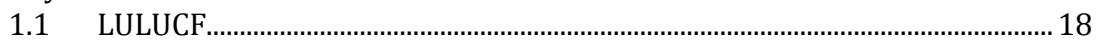

2. International GHG Mitigation Commitments............................................................... 25

2.1 Codification into National Legislation................................................................ 25

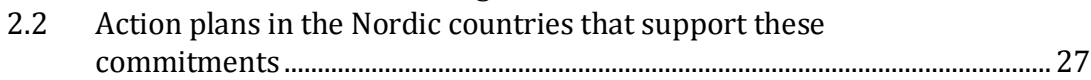

2.3 Relevant Government Institutions and Legal Authorities .............................. 27

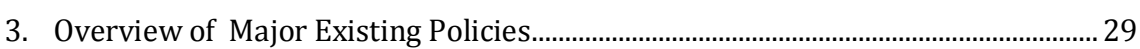

3.1 Economy-wide Measures..................................................................................... 30

3.2 Non-ETS Sectors (All sectors except larger emitters within industry

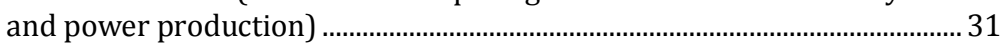

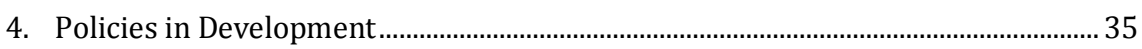

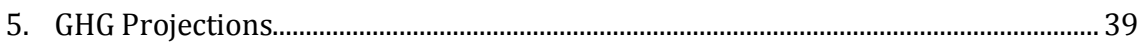

6. Cases for GHG Reduction Policies ................................................................................... 43

6.1 District Heating in Sweden................................................................................ 43

6.2 Wind Power in Denmark ................................................................................... 50

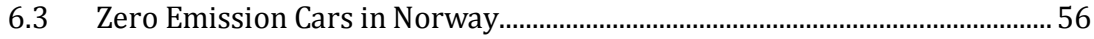

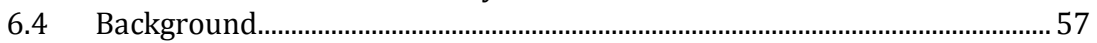

6.5 Low emission cars in Sweden ........................................................................... 64

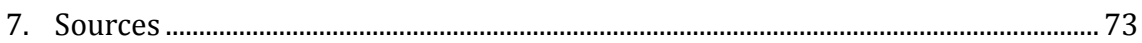





\section{Introduction}

The Nordic countries are often seen as green both in terms of a good environment and being capable of reducing greenhouse gas (GHG) emissions. This report is concerned with the development in GHG emissions over time and with the policies that have been effective in the reduction path.

The Nordic region includes Norway, Sweden, Finland, Denmark and Iceland, all situated in Northern Europe, bordering to Germany in the south and reaching above the Arctic Circle in the north. The five countries, including the autonomous areas of Åland, Greenland, and the Faroe Islands, have a total population of around 25 million and a combined GDP of around $€ 0.7$ trillion (USD 1 trillion).

The Nordic Council and the Nordic Council of Ministers are platforms for ongoing dialogue at the political level as well as at the level of civil servants. This is part of a tradition of exchange of information and experience in the Nordic region. There have also been an increasing number of joint initiatives to use energy resources more efficiently and to implement adequate policy measures to meet the targets set by all countries in the Nordic region.

The project includes a quantitative section based on statistics of the development in GHG emissions. This part comprises the whole Nordic region - Norway, Sweden, Finland Denmark and Iceland - to the extent that data is available. We describe the Nordic region jointly, but the differences between the countries are also significant and will be highlighted. The project also entails a descriptive section, presenting policies and cases on GHG reduction initiatives. This part covers primarily Norway, Sweden and Denmark.

The purpose of the description is both to highlight effective climate policies and to tell the comprehensive story of climate policy in the Nordic countries. One specific objective is to partner with the Open Climate Network, an international network lead by the World Resources Institute. The network develops climate policy landscapes for the major economies of the world, and the Nordic case will form part of such a comparison of policy descriptions, based on the same model used for other countries. 
Four case descriptions provide concrete examples of how general policies in combination with the natural resources of the Nordic region have been transformed into efficient policies for a specific area. The cases are:

- District heating in Sweden.

- Wind power in Denmark.

- Zero emission vehicles in Norway.

- Low emission cars in Sweden.

The project is a result of cooperation between four think tanks and NGOs from the Nordic countries: Zero from Norway, FORES and Global Utmaning from Sweden and CONCITO from Denmark.

The Nordic Council of Ministers and VKR foundation have funded the project. 


\section{Executive Summary}

Over the last decades, the Nordic countries have implemented energy and climate policies to reduce emissions. The commitment to reduce GHG emissions is, and has been, relatively strong among the Nordic countries. In some cases, the policies have been implemented thanks to a national consensus, while in other cases they are the result of intense debates between different stakeholders, interest groups and political parties.

The Nordic countries have reduced fossil GHG emissions by $9 \%$ between 1990 and 2011, while GDP has increased by $55 \%$ over the same period. Looking at the Nordic countries individually, the rate of reduction differs from country to country. While Denmark has contributed with the largest emission reductions (18\%), Iceland has increased its emissions by $26 \%$ Including Land Use, Land Use Change and Forestry LULUCF, the overall reduction is $25 \%$, mainly due to the increased carbon sequestration in Nordic forests in 2011 as compared to 1990.

Nevertheless, the Nordic countries are all above the OECD average in terms of per capita emissions, and only Sweden figures among the ten OECD countries with lowest emissions per capita.

The following factors and climate policies have been important to enable the reduction of GHG emissions:

- An abundance of renewable natural resources puts the Nordic region in a favourable position. Hydropower, geothermal energy, adequate conditions for exploitation of wind energy and large biomass resources are factors that contribute to lowering the GHG emissions from the Nordic countries. In 2010, the fossil share of total Nordic electricity generation was below $17 \%$, while renewables accounted for more than $63 \%$. Considering the total energy consumption and not only electricity, the share of renewable is $30 \%$.

- Policies have been applied in order to utilize these renewable resources in optimal ways, even when it was not necessarily the cheapest option in the short term. Not only climate, but also energy security and reduced import dependency have been the driving reasons for these efforts. This has contributed to a high share of renewable energy in the energy mix. The Nordic countries continue striving to further increase that share. 
- The Nordic governments have set national targets for reducing GHG emissions and, maybe more importantly, the targets have been followed by action plans and initiatives, which have been implemented in more and less efficient ways in the different Nordic countries. The targets and action plans have been monitored and follow-up activities have been set in place, if the policies turned out to be less effective than expected. There has been an ongoing policy loop to retain focus on the reduction targets.

- Energy taxation was introduced early and later carbon taxes followed. The taxes have been important policy instruments for achieving $\mathrm{CO} 2$ emission reductions and for transitioning from fossil to renewable solutions. The combination of taxation and incentives for renewable energy has been a key to the transition undertaken. The taxes are slightly higher than the EU average and have been implemented earlier than in most other European countries. Of all EU countries, Sweden has the highest taxation of heating oil.

- This has created incentives especially for households, and partially also for companies, to reduce energy consumption and replace fossil fuels by renewables. Use of general economic measures has proven effective for reducing and changing energy consumption patterns and has - to a large degree - been accepted by the population.

- The Nordic countries have had comparably few energy subsidies, not even for low-income households. Instead the Nordic countries have ambitious social polices assisting low income families to pay their bills. By avoiding subsidies and using economic support also lowincome families have incentives to reduce energy consumption and use renewable alternatives.

- The cooperation between the national policy level and the local level has proven efficient. At national level the overall framework and economic regulation is set. Several municipalities have taken the lead in a further reduction of GHG emissions by use of local policy. Voluntarily and in a competition to be green, large efforts are made to reduce GHG emissions in many local municipalities.

- The interaction between research, industry and regulation has also been important for achieving GHG emission reductions. Even energyintensive primary industry has improved efficiency and moved towards renewable energy, partly because of economic incentives. Furthermore, new markets for green technologies addressing the challenges of the future have been promoted by environmental and industrial policy. As in other parts of the world, discussions on 
carbon leakage and reduced competitiveness have been lively and are still ongoing, but given the strong economic performance of the Nordic countries, there is little evidence that climate policy has harmed business or welfare.

- Building codes have been used progressively in the Nordic countries to increase energy efficiency and reduce emissions from the residential sector. Though energy use per capita in the residential sector remains high, $\mathrm{GHG}$ emissions are low. The $\mathrm{CO}_{2}$ emissions from heating in Nordic households are $0.2 \mathrm{tCO}_{2}$ per capita. In the OECD Europe, emissions are $0.8 \mathrm{tCO}_{2}$ per capita.

- Waste has been seen as an energy source in the Nordic countries for the last decades and has benn used both in biogas production and for incineration.

- Energy use in road transport in the Nordic countries has increased $23 \%$ since 1990. Policies have been applied to the transport sector to increase the speed with which low emitting cars are introduced.

- Despite rather high GHG emissions from the food value chain, only limited reduction polices have been introduced in the agricultural sector.

- The globalization of the world economy and the growth of industrial production in low income countries have increased indirect $\mathrm{CO}_{2}$ emissions from consumption in the Nordic region. However, such indirect effects are not reflected in official climate data.

- District heating in Sweden has reduced GHG emissions by $30 \%$ Clear price incentives through energy and carbon taxes combined with local governance and planning has been the framework to obtain this reduction.

- Wind power accounted for nearly $30 \%$ of Danish electricity production in 2012 and is planned to account for $50 \%$ by 2020 .

- Windmill production has over the last decades created around 30.000 jobs and a total turnover of $€ 10.7$ billion ( 80 billion DKK). The industry provides $10 \%$ of Danish exports income. This is largely due to effective coordination of public framework conditions, an innovative industry along with favourable international market conditions.

- Norway favours zero emission cars and in September 2013 the market share of rechargeable cars reached $9 \%$ Incentives include no registration fee, no VAT, free parking, free charging and no road toll. 
A clear price signal and long-term predictable policy have been key factors in the success.

- In Sweden, the GHG emissions from private cars have been reduced by around $10 \%$. The carbon tax has likely been one of the major contributing causes to lowering emissions from the transport sector, and emissions would probably have increased without it.

Finally it should be stressed that GHG emission reductions in the Nordic region has to be speeded up in order to meet the challenges associated with climate change. Industrialized countries, like those of the Nordic region, still have high GHG emissions, calling for stronger and more effective policies in the future. Emission reduction targets for 2020 for the Nordic countries vary between 15 to $40 \%$, with an average of $32 \%$. To meet the $2{ }^{\circ} \mathrm{C}$ target set by the IPCC, an additional reduction of $34 \%$ is required in the period between 2011 and 2020.1

${ }^{1}$ According to the IPCC IV main report and Bali-Action plan 40\% reduction by 2020 in Annex I countries are needed. 


\section{Sammenfatning}

De nordiske lande har gennemført en energi- og klimapoltik der har mindsket klimagasemissioner de sidste årtier. Forpligtelsen til at nedbringe drivhusgasemissionerne er, og har været, relativt stærk blandt de nordiske lande. I nogle tilfælde er klimapolitikken blevet gennemført i national konsensus, mens i andre tilfælde kun efter intense drøftelser mellem interessegrupper og politiske partier.

De nordiske lande har reduceret de fossile drivhusgasemissioner med 9 \% mellem 1990 og 2011, mens BNP er steget 55 \% i samme periode. Ser man på de nordiske lande enkeltvis, varierer reduktionerne fra land til land. Mens Danmark har bidraget med de største emissionsreduktioner på $18 \%$, har Island har øget sine emissioner med $26 \%$. Den samlede reduktion er $25 \%$ inkl. LULUCF, primært som følge af øget kulstofbinding i de nordiske skove i 2011 i forhold til 1990 niveauet.

De nordiske lande udleder stadig over gennemsnittet af emissioner per indbygger. Kun Sverige er blandt de ti OECD lande med de laveste emissioner pr indbygger.

De følgende faktorer og klimapolitik har været vigtige for at muligg $\varnothing-$ re reduktion af drivhusgasemissionerne:

- Rigelige vedvarende energiressourcer giver Norden en gunstig position. Vandkraft, geotermisk energi, gode betingelser for udnyttelse af vindenergi og store biomasseressourcer er faktorer, der favoriserer lav drivhusgasemission fra nordiske lande. Den fossile andel af den samlede nordiske elproduktion i 2010 var mindre end $17 \%$ og vedvarende energi udgør mere end $63 \%$ af den samlede nordiske elproduktion. Hvis man betragter det samlede energiforbrug, ikke kun el, er andelen af vedvarende energi $30 \%$.

- Politiske initiativer er gennemført for at udnytte de vedvarende energikilder på bedst mulig måde, også selvom det ikke nødvendigvis er den billigste løsning på kort sigt. Bestræbelserne skyldes ikke blot klimaet, men også forsyningssikkerhed. Det har bidraget til en høj andel af vedvarende energi. De nordiske lande tilstræber at $\varnothing$ ge denne andel yderligere.

- De nordiske regeringer har vedtaget nationale reduktionmål for udledning af drivhusgasser, og måske endnu vigtigere, er målene 
blevet fulgt af handlingsplaner med initiativer, der er blevet gennemført relativt effektivt i de forskellige nordiske lande. Resultaterne af handlingsplanerne er løbende blevet evalueret og hvis en politik har været mindre effektiv end forventet, er der fulgt op med nye tilag.

- Energibeskatning blev tidligt indført, og senere kom $\mathrm{CO}_{2}$ skatter. Skatter og afgifter har været vigtige politiske instrumenter til reduktion af $\mathrm{CO}_{2}$-emissionen og overgangen fra fossil til vedvarende løsninger. Kombinationen af beskatning og incitamenter for vedvarende energi har været centralt for at igangsætte overgangen. Energi og $\mathrm{CO}_{2}$ skatterne i Norden er lidt højere end EU-gennemsnittet og er blevet gennemført tidligere end i de fleste andre europæiske lande. I Sverige er beskatningen af fyringsolie den højeste i forhold til alle EU-lande.

- Det har skabt incitamenter for husholdninger og til dels virksomheder, til at reducere energiforbruget og at erstatte fossile brændstoffer med vedvarende energikilder. Anvendelse af generelle økonomiske virkemedler har vist sig at være effektivt og er i høj grad blevet accepteret af befolkningen.

- De nordiske lande har generelt få tilskud til energi, ikke engang til husstande med lav indkomst. I stedet har de nordiske lande ambitiøse sociale politikker som hjælper lavindkomstfamilier til rimelig velfærd. Ved at undgå tilskud og økonomisk støtte har også familier med lave indkomster incitament til at reducére energiforbruget eller benytte vedvarende alternativer.

- Samarbejdet mellem det nationale politiske niveau og det lokale niveau har været effektivt. På nationalt plan fastlæggers de overordnede rammer og den økonomiske regulering. Flere kommuner har imidlertid taget initiativ til i en yderligere reduktion i drivhusgasemissionerne gennem lokale politike initiativer. Frivilligt og i en konkurrence om at være en grøn kommune er der gjort en stor indsats for at reducere drivhusgasemissionerne i mange kommuner.

- Samspil mellem forskning, industri og regulering har også været vigtig for reduktion af drivhusgasser. Selv energiintensive industrier har forbedret energieffektiviteten og bevæget sig i retning af vedvarende energi på grund af økonomiske incitamenter. Yderligere har nye markeder for grønne teknologier blevet fremmet af miljø-og industripolitik. Som i andre dele af verden er drøftelser om carbon leakage og reduceret konkurrenceevne blevet kraftigt påpeget, og drøftelserne er stadig i gang, men i betragtning af de stærke 
$\varnothing$ konomiske resultater i de nordiske lande er der ikke meget tegn på, at klimapolitikken har skadet virksomheder eller velfærdssamfundet.

- Bygningsreglementer har i de nordiske lande betydet, at energieffektiviteten er øget i nybyggeri. Dog er energiforbruget per indbygger i boligsektoren høj, men drivhusgasudslippet er lavt. CO2udledningen fra opvarmning i de nordiske husstande er 0,2 t CO2 pr indbygger. I OECD Europa emissioner er 0,8 t CO2 per indbygger.

- Affald er blevet opfattet som en energikilde i de nordiske lande i de sidste årtier og bruges i biogasproduktion og i forbrændingsanlæg.

- Energiforbruget i vejtransporten i de nordiske lande er steget $23 \%$ siden 1990, der er blevet indført afgifter på transportområdet for hurtigere at indføre lavemssionsbiler.

- På trods af temmelig høj drivhusgasemission fra landbrug og fødevareproduktion er der kun blevet indført begrænset regulering i landbrugssektoren.

- Globaliseringen af verdens økonomier og vækst i industriproduktion i lavindkomstlande har øget de indirekte CO2-emissioner fra forbruget i Norden. Sådanne indirekte effekter er ikke afspejlet i de officielle klimadata og er derfor ikke inddraget i denne rapport.

- Fjernvarme i Sverige har reduceret drivhusgasemissionerne med 30 $\%$ Klare prisincitamenter via energi- og $\mathrm{CO}_{2}$-skatter, lokal organisering og planlægning af fjernvarmeudbygning samt frit brændselsvalg har været væsentligt for at opnå denne reduktion.

- Ved en koordinering af offentlig rammebetingelser, en innovativ industri og gunstige internationale markedsvilkår tegner vindkraft sig for næsten $30 \%$ af elproduktionen i Danmark i 2012 og er planlagt til at tegne sig for $50 \%$ i 2020. Vindmølle produktionen har i de seneste årtier skabt omkring 30.000 arbejdspladser og en samlet omsætning på €10.7 billion (80 milliarder kroner). Industrien giver $10 \%$ af dansk eksport indkomst.

- Norge favoriserer nul-emissionsbiler og markedsandelen for elbiler nåede $9 \%$ af nye bilssalget i september 2013. Incitamentsystemet omfatter bortfald af registreringsafgift og moms, gratis parkering og opladning samt gratis vejafgift. Et klart prissignal og langsigtet forudsigelig politik har været nøglen til succes.

- I Sverige er drivhusgasemissioner fra privatbiler reduceret med ca. $10 \% \mathrm{CO}_{2}$-afgiften har sandsynligvis været en væsentlig medvirkende årsag til at sænke udledningen fra transportsektoren og emissioner ville sandsynligvis være steget uden.

- Endelig skal det understreges, at reduktion af drivhusgasemissioner i Norden skal fremskyndes for at imødekomme klimudfordringerne. 
Som industrialiserede lande har de nordiske lande stadig høj udledning af drivhusgasser, der kræver stærkere og mere effektive politikker og initiativer i fremtiden. Yderligere reduktion er nødvendig imellem 2011-2020 for at opfylde forpligtelsen fra IPCC om en 2-graders målsætning svarende til ekstra $34 \%$ reduktion. $^{2}$ Reduktionsmål frem til 2020 variererer mellem 15 til $40 \%$ i de forskellige nordiske lande med et gennemsnit på $32 \%$

${ }^{2}$ According to the IPCC IV main report and Bali-Action plan, 40\% reduction by 2020 in Annex I countries are needed. 


\section{Key Metrics}

As presented in Figure 1, aggregate GHG emissions in the Nordic countries have decreased by $9 \%$ in the period 1990-2011 (25\% including Land Use, Land Use Change and Forestry (LULUCF)).

Figure 1 Aggregate Nordic GHG Emissions (Mt CO2e)

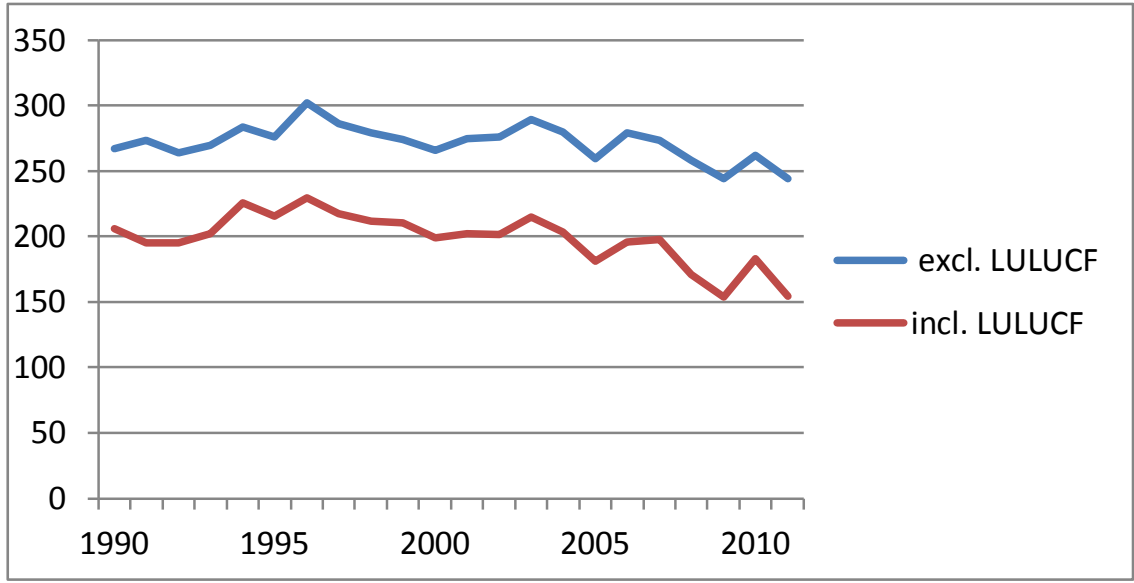

Source: UNFCCC National Inventory Submissions 2013.

The growing difference between emissions with and without LULUCF is due to the increased forest growth and not because of any specific climate policy to address LULUCF.

Looking at the Nordic countries individually, reduction rates vary from country to country. While Denmark has contributed with the largest emission reductions (18\% excl. LULUCF; $27 \%$ incl. LULUCF) Iceland has increased its emissions (26\% excl. LULUCF; $10 \%$ incl. LULUCF) as shown in Figure 2. 
Figure 2: Nordic GHG emissions at country level (Mt CO2e)
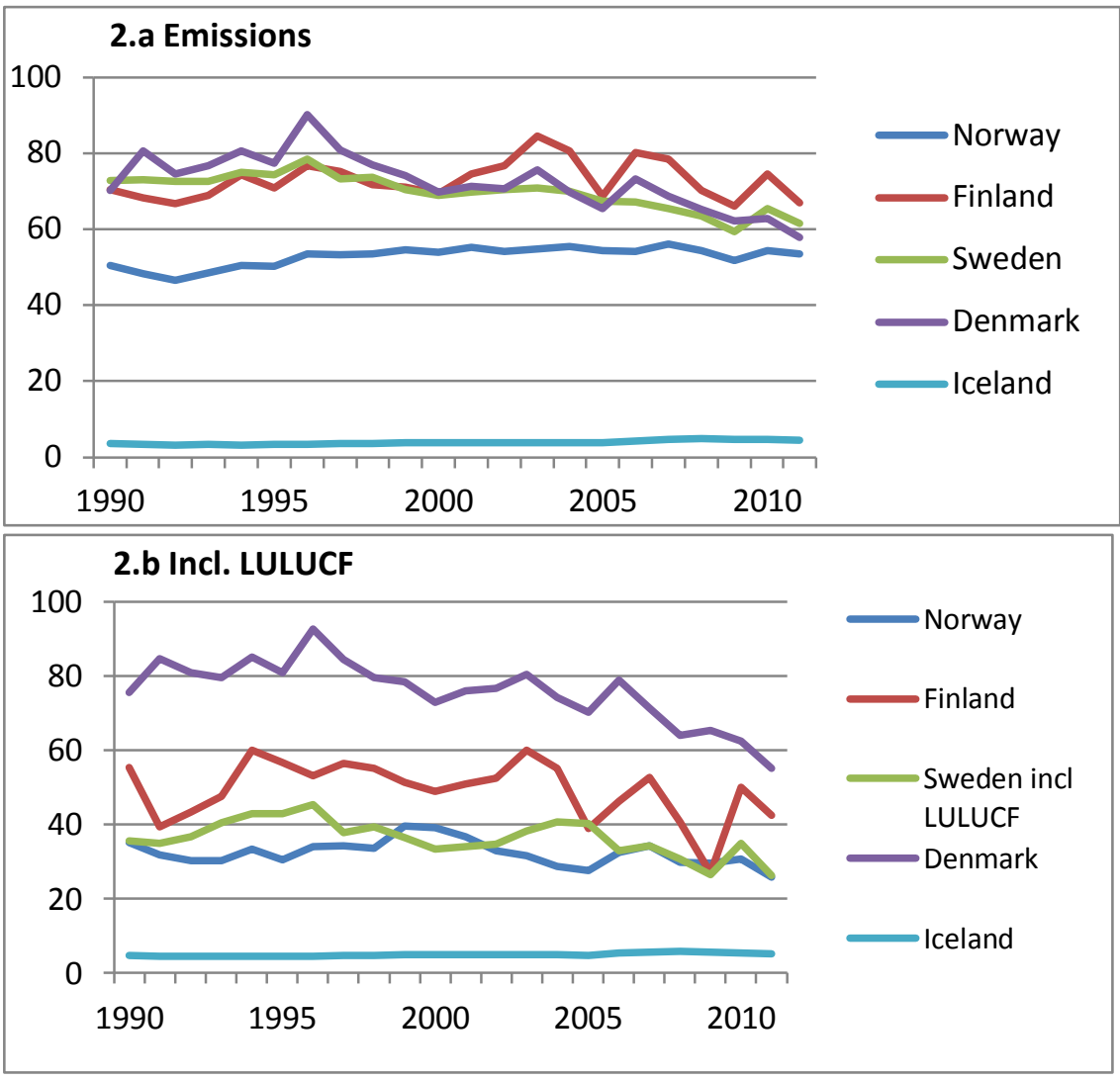

Source: UNFCCC National Inventory Submissions, 2013. Emissions for Denmark include Faroe Islands and Greenland. Emissions for Finland include Åland.

\subsection{LULUCF}

The relatively large reductions achieved by LULUCF are primarily due to developments in forest growth and forestry, which have been significant in all the Nordic countries except Sweden.

Most of the forest in Norway was cut down a century ago. An ambitious reforestation policy in the first half of the $20^{\text {th }}$ century is resulting in an increasing volume of timber in the Norwegian forests. The carbon uptake is at its highest level now and is projected to decrease over the coming decades according to official forecasts.

Sweden, however, had already in 1990 a far larger uptake from forestry than any other Nordic country in absolute terms; a lead that still persists in 2011 despite an increased uptake from forests by $57 \%$ in Finland and $78 \%$ in Norway in 2011 since 1990. In 1989, the Danish Parliment 
adopted a resolution to double the forest cover over a tree generation, which has resulted in Denmark having achieved the greatest relative increase in uptake from forests, though from an initial negative level.

The following two figures show emissions from LULUCF for 2011 and the development in LULUCF from 1990 to 2011. The figures highlight the importance of LULUCF for the net emissions of the Nordic countries. One should bear in mind, however, that accounting for LULUCF is less well-documented than for fossil $\mathrm{CO} 2$ emissions.

Figure 3: The first figure shows LULUCF in 2011 and the second figure shows the development from 1990-2011
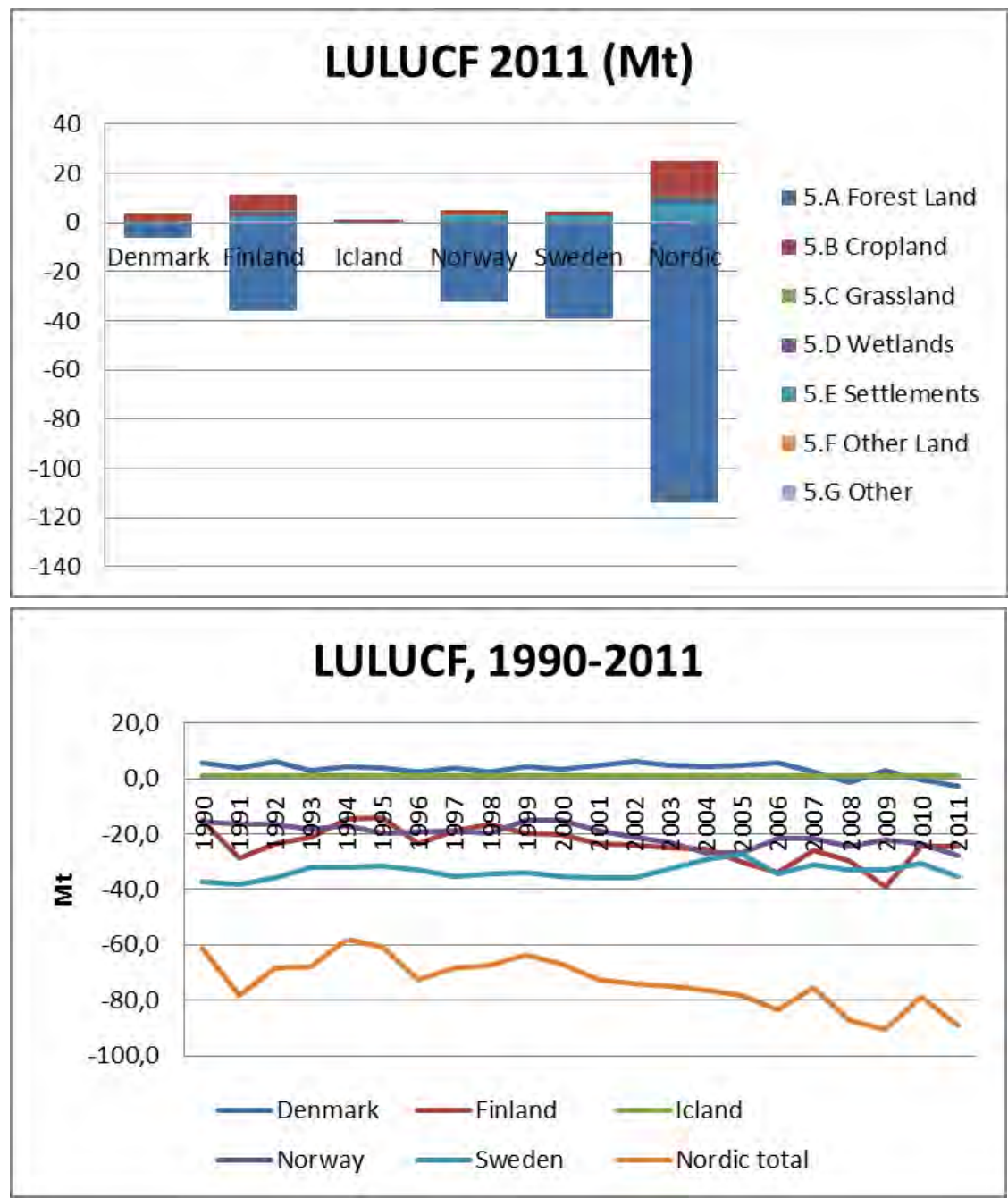

Source: UNFCCC 
Figure 4a shows that Nordic per capita CO2e emissions were reduced by $22 \%$, while emission intensity has improved by $41 \%$ from 1990 to 2011. Underlying these numbers is an $11 \%$ increase in population and a $55 \%$ increase in GDP since 1990, implying an $39 \%$ increase in GDP per capita as seen in figure $4 \mathrm{~b}$.

Figure 4.a: Nordic $\mathrm{CO} 2$ emissions per capita and $\mathrm{CO} 2$ emission intensity. Figure 4.b: The development in Nordic GDP per capita (in USD) since 1990
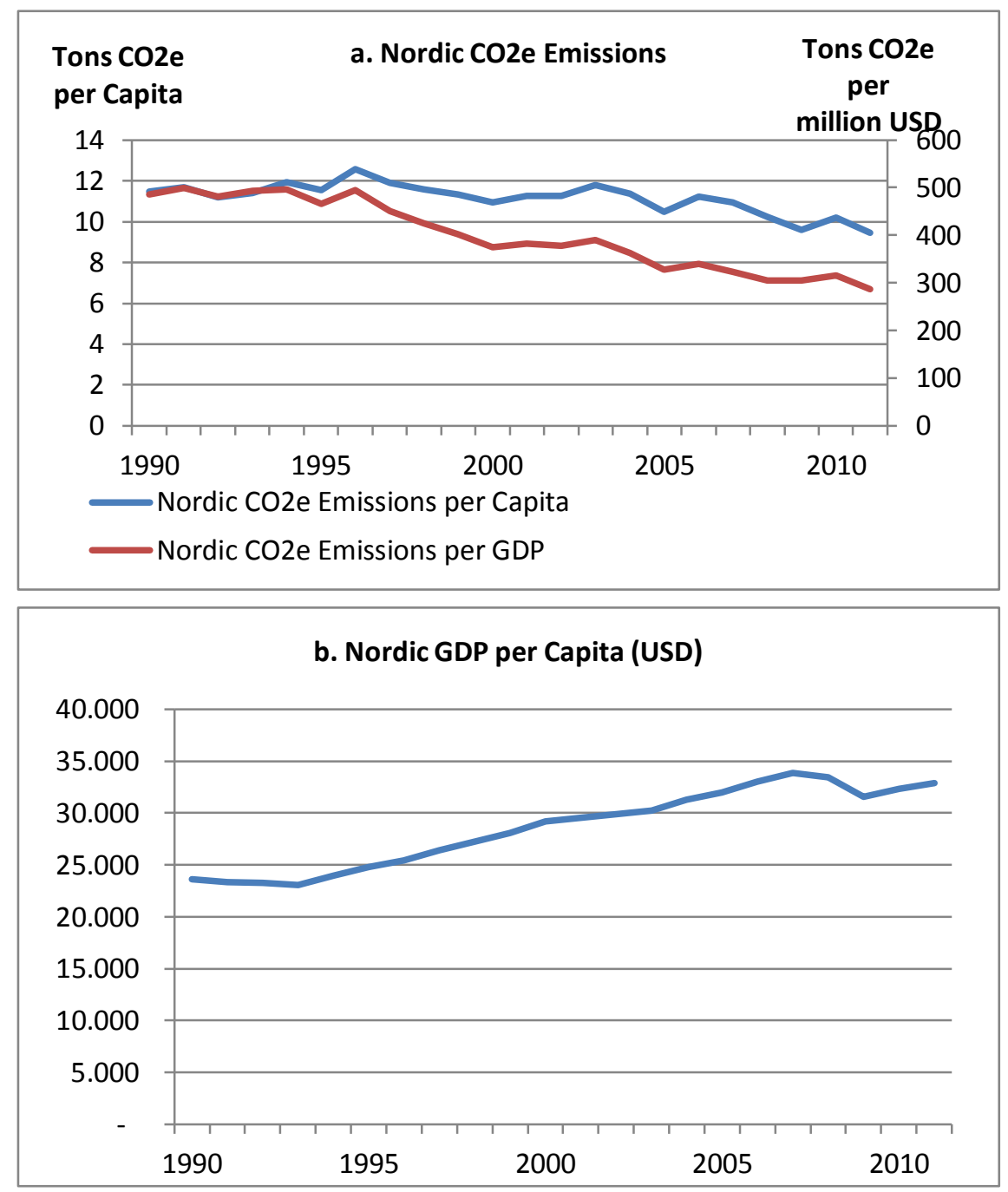

Source: UNFCCC and the World Bank. 
Compares the Nordic countries with the rest of the OECD countries. The Nordic countries are still all above average in terms of per capita emissions. Only Sweden is among the ten countries with the lowest emissions per capita. Iceland has a very high per capita emission primarily due to an energy-intensive industry and high per capita emissions in the sector. Neither the high emissions per capita nor the differences between the Nordic countries have a simple explanation. Causes include a cold climate, a high GDP per capita, industrial structure, naturally existing energy resources and differences in climate policy.

Figure 5: GHG emissions per capita in 2011.

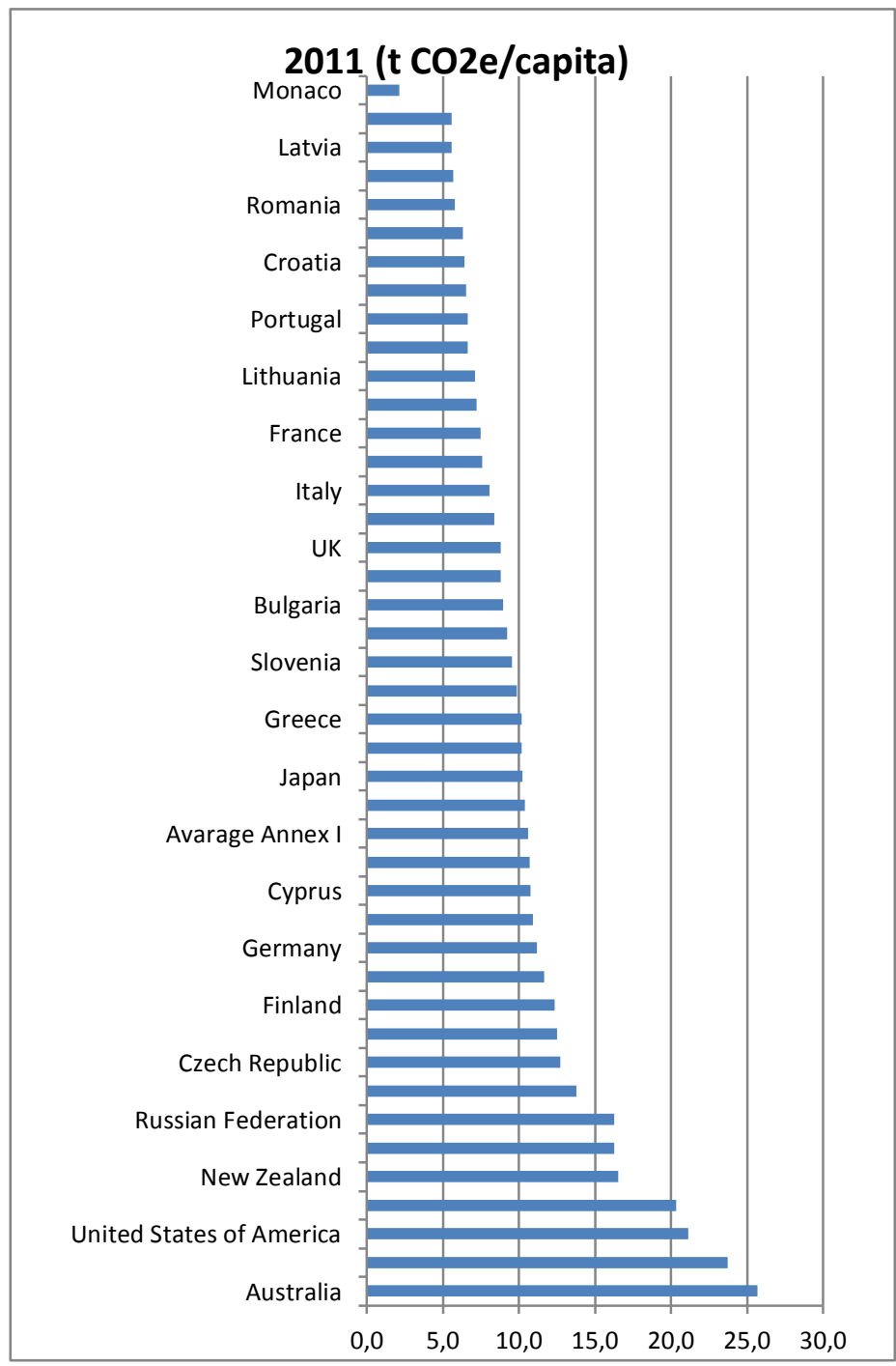

Source: UNFCCC 
Figure 6 shows the development in the energy intensity of the Nordic region compared with the average intencities for the OECD countries and the world. It shows that the Nordic region's energy intensity is above the OECD average. This is mainly due to a high concentration of energy-intensive industry and a substantial petroleum industry in the Nordic countries (International Energy Agency, 2013). However, from the 1990s until 2009, the Nordic countries have improved energy intensity by $30 \%$ compared with a $23 \%$ improvement in both OECD and world averages.

The sudden increase in Nordic energy intensity in 2010 seems to be an isolated effect as figures fell again in 2011 to a level below 2009.

Energy intensity varies considerably among the Nordic countries with Finland being twice as energy-intensive as Denmark and Iceland being three times as energy-intensive as Denmark. Together with Ireland, Denmark has the lowest energy intensity of all EU countries.

Figure 6: Nordic energy intensity (GJ/USD) compared to world and OECD averages

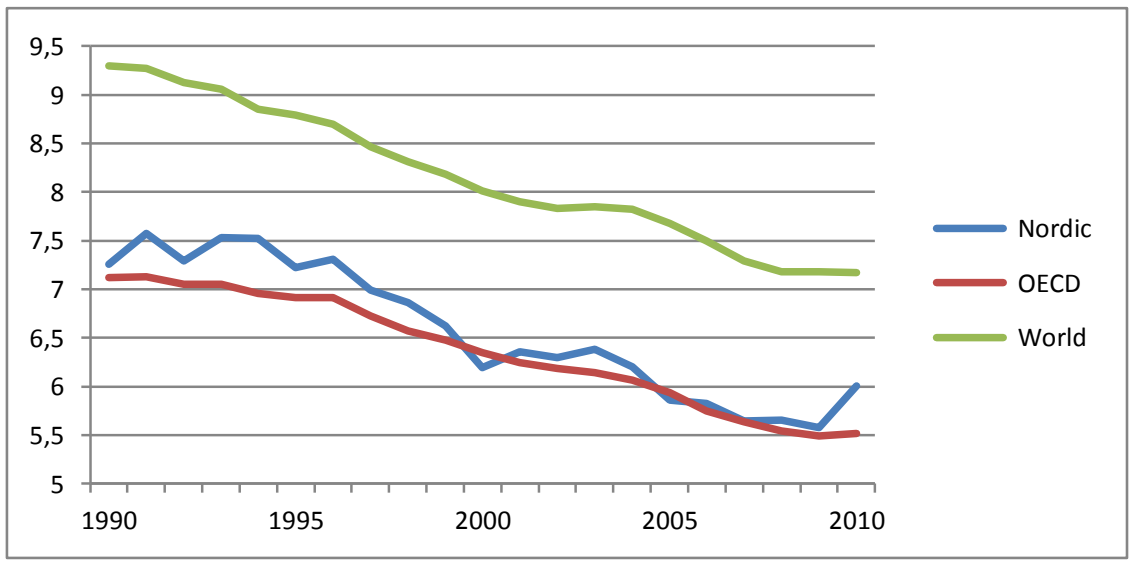

Source: International Energy Agency (2013).

Figure 7 shows the aggregate energy mix in electricity generation in the Nordic countries. While the fossil share was below $17 \%$ and nuclear accounted for around $20 \%$, renewables made up more than $63 \%$ in 2010. Within the renewable share, hydropower is by far the largest contributor and accounted for a total of $52 \%$. 
Figure 7: Nordic energy mix in electricity generation (TWh), 2010

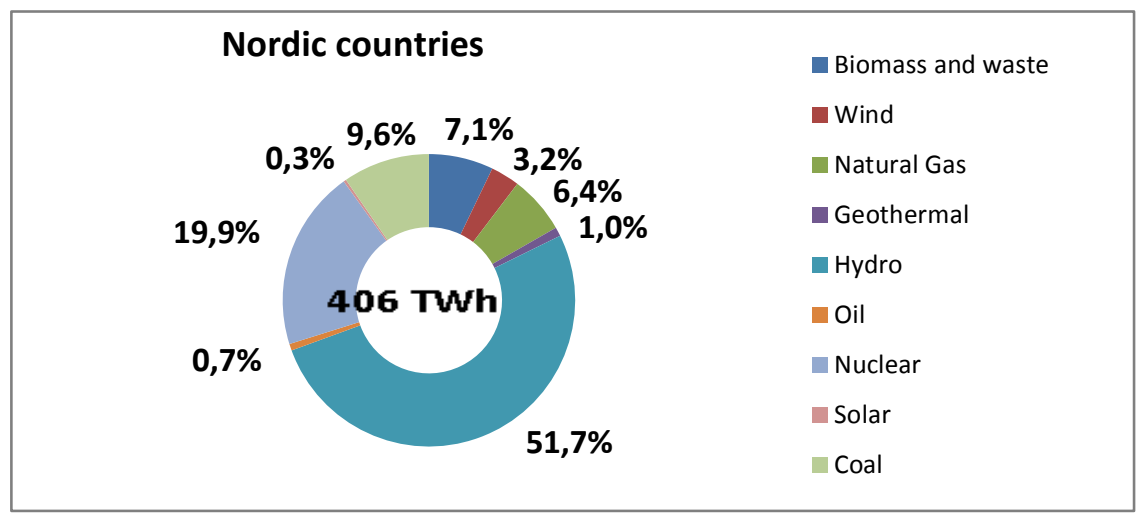

Source: International Energy Agency (2013).

Looking at the energy mix in electricity generation by country, it shows a large diversification between the Nordic countries. This is reflected in Figure 8, which shows a fossil share in Denmark of $64 \%$ and in Finland of $40 \%$ compared with $5 \%$ in Sweden, $4 \%$ in Norway and nothing in Iceland.

Figure 8: Energy mix in electricity generation by country (TWh), 2010

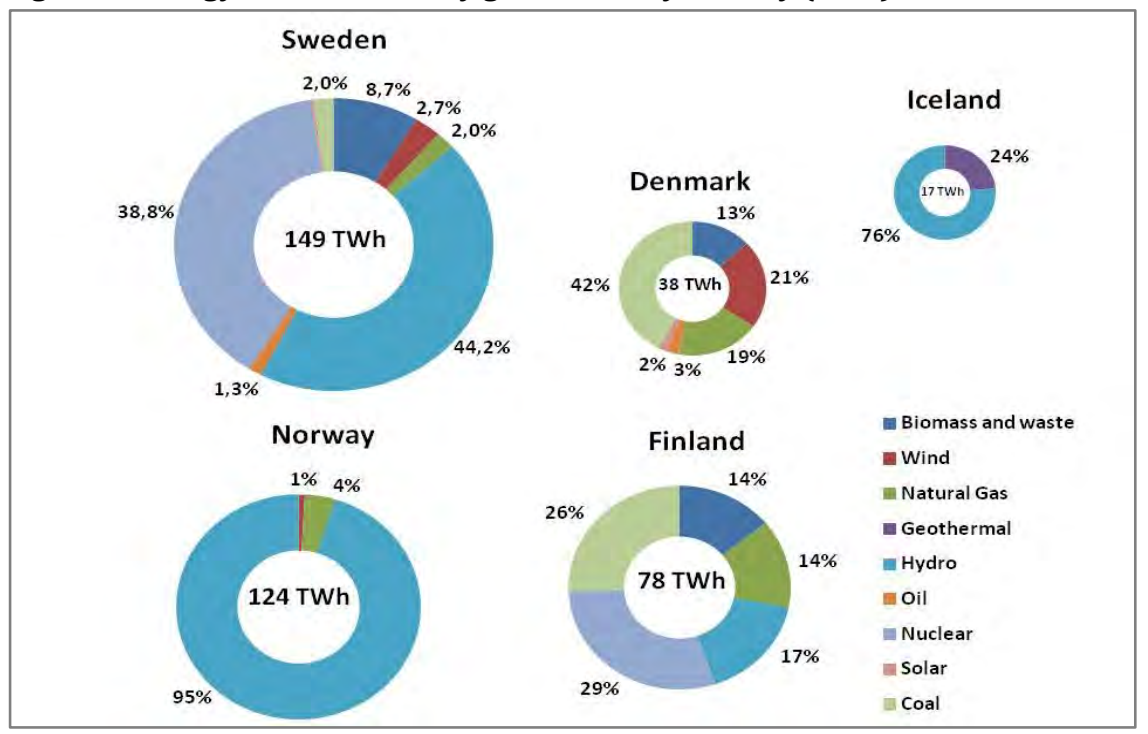

Source: International Energy Agency (2013)

The Nordic countries have developed an advanced cross border electricity market, where the different production portefolios complement each other and contribute to energy security and stabler prices. The common 
electricity market also allows for a larger proportion of renewable energy since fluctuations in production even out between regions and can be balanced by hydropower production.

Considering the total energy consumption and not only electricity, the aggregate Nordic picture changes considerably. The share of renewable is $30 \%$ of the total energy consumption as compared to $52 \%$ in electricity production. Of the total energy consumption, oil accounts for $32 \%$, coal for $10 \%$ and gas for $11 \%$ In particular, the transport sector is based on oil. The use of coal is high in Denmark and Finland, accounting for $20 \%$ of total energy consumption. In contrast, Norway and Sweden have a coal share of less than $5 \%$ Gas plays a substantial role in Denmark and Norway, accounting for around $20 \%$ of energy consumption in both countries. For Finland, this figure is approximately $10 \%$

Figure 9: Energy mix in total energy consumption in the Nordic countries, 2010 (except Iceland)

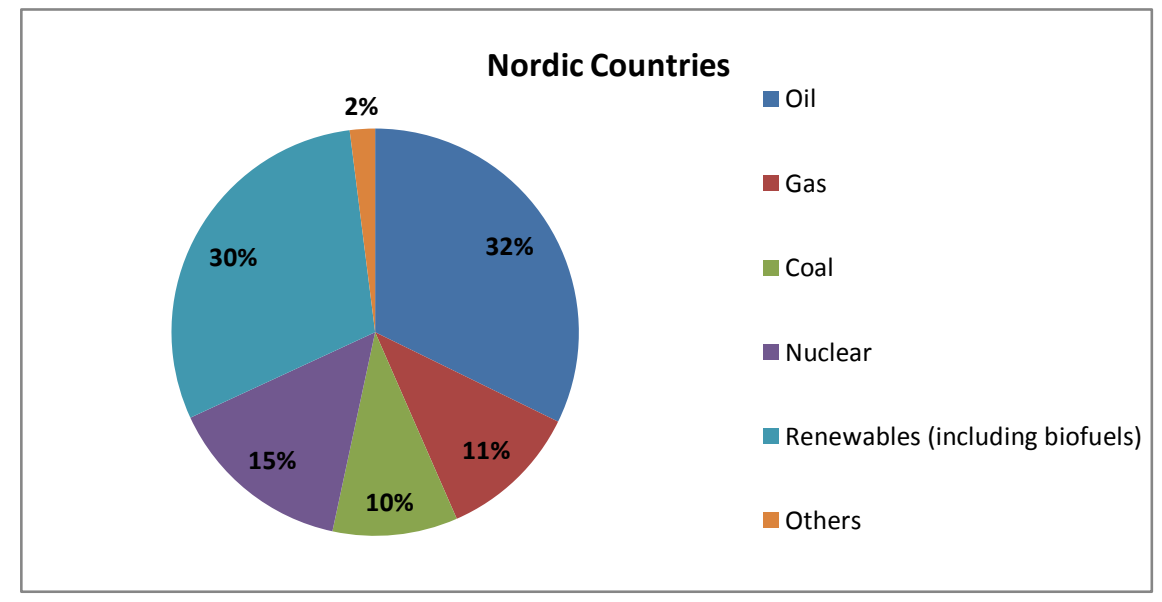

Source: http://www.ens.dk/info/tal-kort/statistik-nogletal/nogletal/internationale-nogletal 


\section{International GHG Mitigation Commitments}

The Nordic countries, excluding the Faroe Islands, are all parties to the Kyoto Protocol. Åland is included in the Finish obligations and Greenland was taking part in the Danish Kyoto obligations in the first period. Further, Denmark, Finland and Sweden also have international emission reduction commitments as members of the EU. Greenland does not share Denmark's EU obligations, as Greenland is not a member of the EU.

Table 1 shows the national emission reduction targets (shown as "-") or limitation targets (shown as "+") as agreed to internationally. For the first commitment period of the Kyoto Protocol 2008-2012, the joint EU obligation is shown for the Nordic countries that are members of the EU as well as the burden sharing commitment in parentheses. Norway and Iceland, as the Nordic members of the Protocol that are not members of the EU, submitted individual mitigation targets for the first commitment period.

For the second commitment period, burden sharing has not yet been settled internally within the EU. Therefore, the table shows the shared EU obligation of $20 \%$ reductions for the Nordic EU-members. This includes provisions for possibly increasing reduction efforts to $30 \%$ for 2020, pending an international agreement on a post-2020 regime.

Further, for the second commitment period 2013-2020, it is expected that Iceland fulfil its obligation jointly with the EU.

\subsection{Codification into National Legislation}

The EU Climate and Energy Package enacted in 2009 realises the EU's commitments for 2020. The package includes the Effort Sharing Decision, which codifies into binding national legislation sharing the EU overall target of a $10 \%$ reduction in the non-ETS sectors by 2020 compared to 2005. 
Table 1: Commitments under the UNFCCC

\begin{tabular}{llll}
\hline Country & Kyoto CP I 2008-2012 & Kyoto CP II 2013-2020 & Sectors and sources \\
\hline Denmark & $-8(21)$ & -20 & EU ETS \\
Faroe Islands & $/$ & $/$ & $/$ \\
Finland & $-8(0)$ & -20 & EU ETS \\
Greenland & -8 & -20 & \\
Iceland & +10 & $-20^{3}$ & \\
Norway & +1 & $-30^{4}$ & EU ETS \\
Sweden & $-8(+4)$ & -20 & EU ETS \\
Åland $^{5}$ & $-8(0)$ & -20 & \\
\hline
\end{tabular}

Source: UNFCCC and International Energy Agency (2013).

Table 2 shows the national targets for the Nordic EU member countries in the non-ETS sectors. For Finland, this obligation corresponds to the national effort sharing for 2020, while for Sweden the national target is considerably more ambitious than the EU obligation. The Danish and Norwegian targets are total national emissions reductions and not just the non-ETS sectors. Despite not being members of the EU, both Norway and Iceland participate in the EU ETS and will realise part of their obligations through this measure.

Table 2: National emission reduction targets

\begin{tabular}{|c|c|c|c|c|}
\hline Country & $\begin{array}{l}\text { EU Effort } \\
\text { Sharing }\end{array}$ & $\begin{array}{l}\text { National targets } \\
\text { for } 2020\end{array}$ & $\begin{array}{l}\text { National targets for } \\
2050\end{array}$ & $\begin{array}{l}\text { Use of Offsets in the } \\
2050 \text { target }\end{array}$ \\
\hline Denmark & $20 \%$ & $40 \%^{6}$ & $100 \%$ fossil free ${ }^{7}$ & No \\
\hline Faroe Islands & & $20 \%^{8}$ & & No \\
\hline Finland & $16 \%$ & $16 \%^{9}$ & $80 \%$ (domestic) & No \\
\hline \multicolumn{5}{|l|}{ Greenland } \\
\hline Iceland & & $15 \%$ & $50-75 \%$ & Possibly \\
\hline Norway & & $30 \%{ }^{10}$ & $100 \%(\text { net })^{11}$ & Possible \\
\hline Sweden & $17 \%$ & $40 \%{ }^{12}$ & $100 \%$ (net) & Possibly \\
\hline Åland ${ }^{13}$ & $16 \%$ & $16 \%$ & $80 \%$ (domestic) & No \\
\hline
\end{tabular}

Source: UNFCCC and International Energy Agency (2013)

\footnotetext{
${ }^{3}$ Iceland is expected to fulfil its second commitment period Kyoto obligation, 2013-2020, jointly with the EU. ${ }^{4}$ Minimum 2/3 to be done nationally. Possibility of increasing target to $40 \%$ pending international agreement.

5 Åland's obligations are included in the Finish obligations

${ }^{6}$ Both ETS and non ETS sectors

${ }^{7}$ Corresponds to approx. $85 \%$ emission reductions according to the International Energy Agency 2013, referencing the Danish Climate Change Policy Commission's calculations.

8 Baseline 2005. Domestic emissions incl. shipping and aviation. No offsets.

${ }_{9}^{9}$ The target covers non-ETS sectors

${ }^{10}$ Reduction of GHG emissions includoing offsets

11 Incl. possibility for raising ambitions to realising the $100 \%$ target already by 2030 pending international agreement.

12 The target covers non-ETS sectors. $1 / 3$ can be offset

13 Åland's obligations are included in the Finish obligations
} 


\subsection{Action plans in the Nordic countries that support these commitments}

The targets in all countries are followed by a national action plan, describing the measures to be applied to meet the targets. The general picture across the countries is impact assessments of a number of measures, which lead to a national action plan with specific initiatives. The cost of reducing GHG emissions is calculated and forms the basis for the political decision on each initiative. Following this, the necessary legislation will be decided. The current action plans are the following:

- Denmark: http://www.ens.dk/sites/ens.dk/files/dokumenter/ publikationer/downloads/accelerating_green_energy_towards_2020.pdf

- Norway: "Klimakur2020" http://www.miljodirektoratet.no/klimakur/

- Sweden: En sammenhållan klimat och energipolitik - Klimat http://www.regeringen.se/content/1/c6/12/27/78/4ce86514.pdf

- Finland: Nationell energi- och klimatstrategi, statsrådets redogörelse till riksdagen, 20.3.2013 (pdf) (403 KB)

- Island: 2010 Action Plan, presentation: https://notendur.hi.is/ thorstur/teaching/UAU106/2012_HugiO_Climate.pdf

\subsection{Relevant Government Institutions and Legal Authorities}

The European Union for Denmark, Finland and Sweden that are members of the EU, climate and energy matters are areas of "shared competence" between the EU and national governments. This implies that legal action is taken at the appropriate level, with member states exercising their competences in areas, where the EU is not mandated to do so. International commitments for Denmark, Finland and Sweden are entered into by the EU, with the EU ETS covering the largest share of emission reductions. Member states define how to implement Effort Sharing measures to reach their targets within the non-ETS sectors.

The Nordic Council of Ministers is a forum of ministers at the Nordic level, comprising most sectors, including energy and climate. The forum works as platform for exchanging experience and has no legal powers.

National government institutions have responsibility for domestic climate policy and therefore also for the implementation of reduction targets. In all countries, a ministry has the overall responsibility and delegate part of the area to national agencies. The electricity grids are 
partly under public ownership as a natural monopoly regulated by the state. Taxation is managed by the Ministry of Finance, and in most countries, sectoral ministries, such as for transport and housing, have separate climate plans. However, together, the national targets and action plans constitute joint policy plans and are being implemented as such.

Municipalities: Local authorities have no direct legal obligations to reduce GHG emissions. However, in all countries a large number of municipalities set up their own reduction targets and establish action plans to meet these targets. The municipalities often have reduction targets for areas they manage directly.

They set stricter standards than the minimum requirements from the national level and implement GHG reductions based on the national framework. The responsibilities of the municipalities include:

- Land use planning

- Supply of public transport, transport regulation, local roads- and bicycle infrastructure.

- Waste treatment, comprising production of biogas or incineration for combined heat (district heating) and power production.

- Energy codes for new buildings and refurbishment of older buildings, which are strickter than the national standards.

- Commonly, but not part of legal responsibility: District heating and electricity production and distribution. 


\section{Overview of Major Existing Policies}

The overall policy framework in the Nordic countries is more or less the same, but implemented with national variations. There are also examples of instruments implemented only in one or two countries. The table below presents both policies, which are implemented in several or all countries, and relevant examples of policies implemented only in one country. In section VI, four cases are presented describing a combination of policy measures used to drive specific GHG reductions.

Information and awareness raising campaigns have also formed part of the climate policy in all the Nordic counties. However, those measures are not described in detail below and it is difficult to evaluate their results. In general, the population of the Nordic countries is considered well aware of environmental issues and concerned about the possible impacts of climate change.

\begin{tabular}{|c|c|c|c|}
\hline Sector & Policy area & Specific policy & Country \\
\hline \multirow[t]{4}{*}{ Energy } & $\begin{array}{l}\text { Support for renewable } \\
\text { electricity (RE) production }\end{array}$ & Certificates for RE. & $\begin{array}{l}\text { A joint cross-border } \\
\text { system between } \\
\text { Norway and Sweden }\end{array}$ \\
\hline & & $\begin{array}{l}\text { Subsidies for RE by a feed-in tariff and } \\
\text { tendering of offshore wind. }\end{array}$ & Denmark, Finland \\
\hline & $\begin{array}{l}\text { Reduction commitments } \\
\text { for energy companies }\end{array}$ & Annual reduction targets. & Denmark \\
\hline & $\begin{array}{l}\mathrm{CO} 2 \text { tax for petroleum } \\
\text { production }\end{array}$ & Tax of 410 NOK / tCO2. & Norway \\
\hline \multirow[t]{6}{*}{ Transport } & Car tax & CO2-differentiated purchase tax. & $\begin{array}{l}\text { Norway, Denmark, } \\
\text { Finland }\end{array}$ \\
\hline & & CO2-differentiated annual tax. & All except Iceland \\
\hline & & Fuel tax. & All \\
\hline & $\begin{array}{l}\text { Incentives for low emis- } \\
\text { sion vehicles }\end{array}$ & Rebate at purchase. & Sweden \\
\hline & & No purchase tax and no annual tax. & Denmark, Norway \\
\hline & $\begin{array}{l}\text { Introduction of cleaner } \\
\text { fuels }\end{array}$ & $\begin{array}{l}\text { Mandatory for fuel stations to offer } \\
\text { biofuels. }\end{array}$ & $\begin{array}{l}\text { Sweden } \\
\text { Norway, Sweden, }\end{array}$ \\
\hline
\end{tabular}




\begin{tabular}{|c|c|c|c|}
\hline Sector & Policy area & Specific policy & Country \\
\hline & & $\begin{array}{l}\text { Mandated biocontent in fuels. } \\
\text { Reduced energy tax for biofuels } \\
\text { (which also has no } \mathrm{CO} 2 \text { tax). }\end{array}$ & $\begin{array}{l}\text { Finland and Denmark } \\
\text { Sweden, Norway }\end{array}$ \\
\hline & & Public support for charging facilities. & Norway, Denmark \\
\hline \multirow[t]{4}{*}{ Buildings } & Low energy housing & Building codes for new buildings & All \\
\hline & & $\begin{array}{l}\text { Building codes for renovation of } \\
\text { existing buildings }\end{array}$ & $\begin{array}{l}\text { Sweden, Norway, } \\
\text { Finland }\end{array}$ \\
\hline & District heating & $\begin{array}{l}\text { System design and } \mathrm{CO} 2 \text { taxation. } \\
\text { Government support to district } \\
\text { heating systems. }\end{array}$ & $\begin{array}{l}\text { Sweden, Denmark, } \\
\text { Finland, Norway } \\
\text { Norway }\end{array}$ \\
\hline & Reduce oil for heating & Mandatory phase out of oil burners. & Norway, Denmark \\
\hline Industry & Increase energy efficiency & Support schemes. & $\begin{array}{l}\text { Norway, Denmark, } \\
\text { Sweden }\end{array}$ \\
\hline
\end{tabular}

Sources: Nordic Energy Technology Perspectives NER and International Energy Agency, 2013.

\subsection{Economy-wide Measures}

All the Nordic countries have taxes on energy and $\mathrm{CO} 2$ emissions, but at differing levels and with varying coverage and exceptions. The taxes are important policy instruments for achieving $\mathrm{CO} 2$ emission reductions and for transitioning from fossil to renewable solutions. The combination of taxation and incentives for renewable energy has been key to the transition undertaken. Taxes in the Nordic countries are slightly higher than the EU average and have been implemented earlier than in most other European countries.

Figure 10: CO2 and energy taxes, $€ / L$.

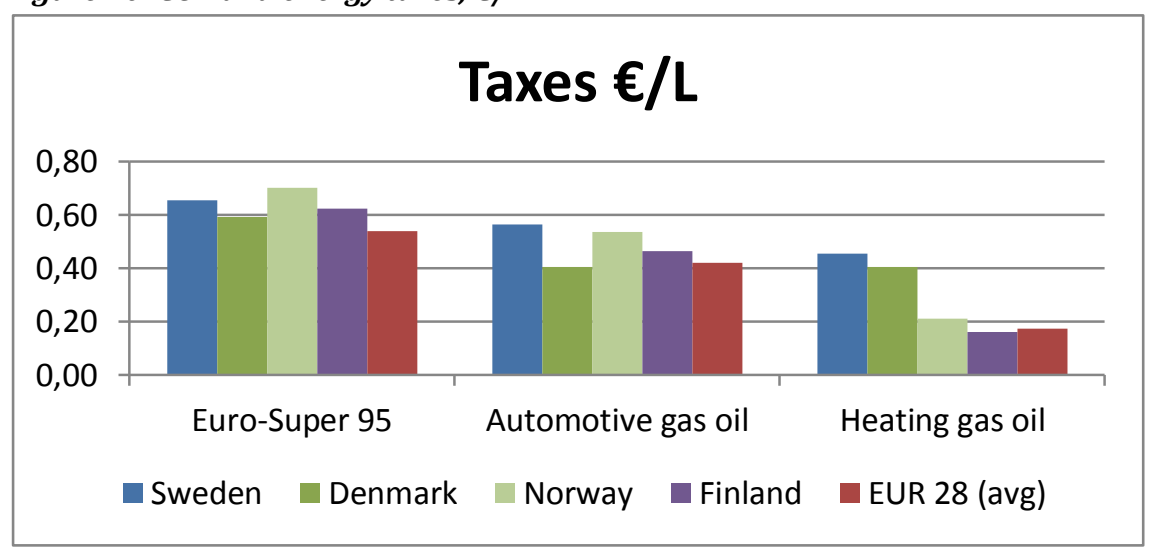

Source: europa.eu/energy/observatory. 
Sweden has the highest taxation of heating oil among all EU countries, with Denmark likewise being in the upper range. ${ }^{14}$

For gasoline, Norway, Sweden, Finland and Denmark are all in the upper half, but the differences between the individual countries are smaller than is the case for heating oil. The same situation goes for diesel, though Denmark in this case is a bit below the EU average.

\subsection{Non-ETS Sectors (All sectors except larger emitters within industry and power production)}

The following presents the major existing policy measures in the Nordic countries in the building, transport and land use sectors and their expected effects on emission reductions.

\subsubsection{Buildings}

The Nordic countries have considerable higher energy consumption per household for heating and electricity in residential buildings as compared to the rest of Europe. Figure 11 shows that the Nordic residential energy consumption is $27 \%$ larger than the for the average European OECD countries. This is mainly due to a higher income and a large housing area per capita.

Figure 11: Household energy use and direct $\mathrm{CO2}$ emissions for heating and electricity in the residential sector, 2009

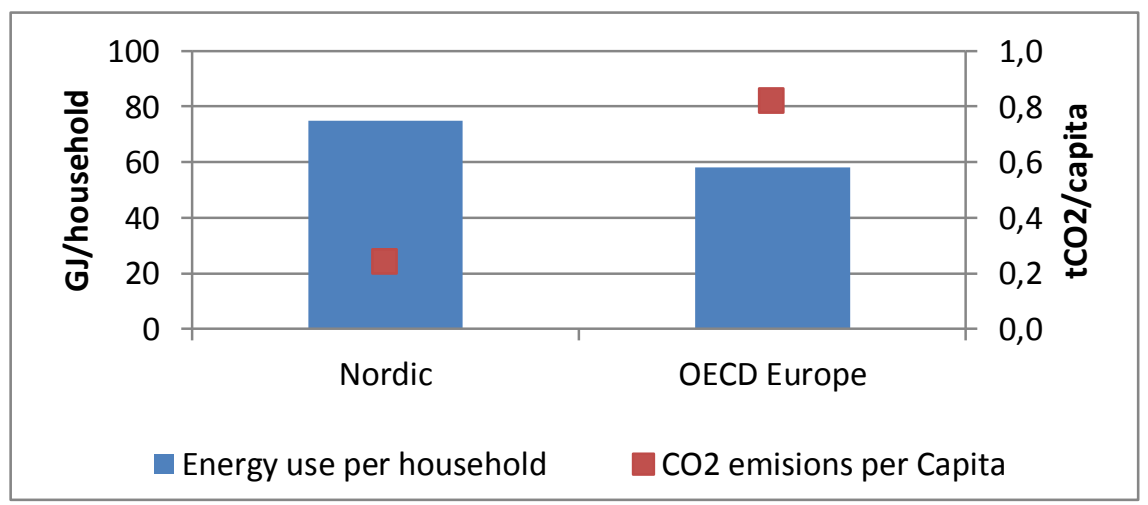

Source: International Energy Agency (2013).

${ }^{14}$ Source: Market observatory \& Statistics, EU. Oil Bulletin Newsletter: http://ec.europa.eu/energy/ observatory/oil/bulletin_en.htm 
The Nordic approach to GHG reduction in the building sector has been a transformation from fossil fuels to renewable sources. The $\mathrm{CO} 2$ emissions from heating and electricity in Nordic households are 0.2 tCO2 per capita. In OECD Europe, emissions average 0.8 tCO2 per capita. The case descriptions on district heating and wind power will give examples of policies in this field.

\subsubsection{Transport}

Energy use in road transport in the Nordic countries has increased by 23 $\%$ since 1990, and accounted for $69 \%$ of total Nordic transport in 2010 , measured by energy use. This is shown in Figure 12 .

\section{Figure 12: Nordic energy use in transport (PJ)}

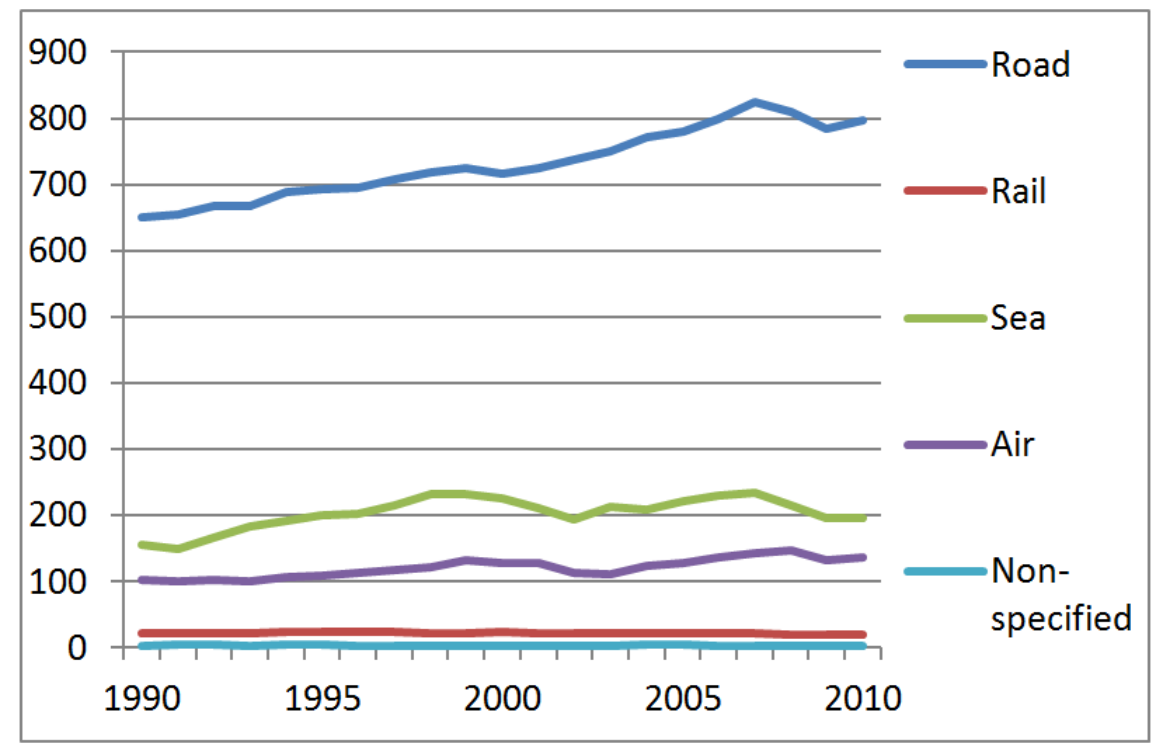

Source: International Energy Agency (2013).

The EU has CO2 standards for vehicles as well as a fuel quality directive and a renewable energy directive, including a specific target of $10 \%$ renewable fuels by 2020 .

National policies in this field seek to further encourage the use of renewable energy in the transport sector and taxation is used as a means to push the introduction of energy efficiency and vehicles that can use renewable fuels. The cases on electric vehicles and carbon taxation in the transport sector provide examples of policies in this field. 


\subsubsection{Waste}

Waste has been seen as an energy source in the Nordic countries for several decades. Organic household waste is used for biogas, especially in Sweden, and other waste is used for district heating and combined heat and power generation, predominantly in Sweden and Denmark.

\subsubsection{Agriculture, Forestry and Other Land Use}

Despite rather high GHG emissions from the food value chain, only limited reduction polices have been introduced in the agricultural sector. Part of the explanation for this is that the harmonization of agricultural policy within the EU limits the manoeuvring space of national governments in this sector. Within the EU support schemes, Sweden and Denmark have introduced measures to reduce methane leakage from agriculture through information campaigns and grants for specific investments.

Policies to increase total forest cover have been implemented in Denmark. Nevertheless, this has a very small impact on overall figures for the region, due to greater forest areas in the other Nordic countries.

\subsubsection{Industry}

The industry has been impacted by general economic instruments, such as energy taxes and carbon taxes. However, sectors that have been subject to international competition and are included in the EU ETS have in many cases been exempt or allowed reduced levels of such taxes.

Denmark, Norway and Sweden have had specific support schemes to incentivize both large primary industry and smaller companies to increase energy efficiency. 



\section{Policies in Development}

In the Nordic countries, reduction of GHG emissions is an active area of policy development. With rather ambitious targets, new initiatives must be implemented.

In all countries, the policy cycle looks as follows:

- Define reduction targets.

- Identify the adequate packages of policy measures.

- Implement the identified measures.

- Tracking GHG emissions and assessing the impact of implemented policies.

- Identify the gap between targets and development.

- Identify additional policies.

New measures and policy initiatives in the pipeline or currently being discussed, include:

- Climate Law

Some Nordic countries are following the UK example of implementing a law on carbon reduction targets. In Denmark, a climate law is expected to be passed by parliament in 2014 and in Norway a discussion of this policy measure is ongoing. In Finland, a climate law has been suggested by a national panel of experts on climate change and is currently in process within government. In Sweden, a climate law has been proposed by some opposition parties in the parliament.

As of today, overall national climate targets in the Nordic countries are commonly set through decisions in parliament, but there is no specific or strict legal framework for the follow-up of these targets.

- Reduction Initiatives in the Agricultural Sector In Denmark, a number of policy instruments to reduce GHG emissions have been tabled by Government. All together 18 measures are being debated, ranging from reforestation and taking organic soils out of production over taxing manure not being used for biogas production to putting lids on manure containers. However no decisions have been made yet. In Sweden, the government has 
proposed a support scheme for reducing methane emissions in biogas production, planned to take effect from 2014.

- Further Use of the Tax Instruments

In Norway, a green tax commission will be formed to propose a new green tax reform to contribute to meeting reduction targets. In Denmark, a shift in the taxation of the transport sector is being prepared. In Sweden, the high CO2 taxation of about $€ 139 / \mathrm{tCO} 2$ (USD 190/tCO2) has led to large reductions for the industry outside of ETS including forestry and agricultural sectors. The reductions of the $\mathrm{CO} 2$ tax for industry are gradually being phased out, following a long-term scheme to increase incentives for $\mathrm{CO} 2$ reductions also in these sectors. In 2015, the CO2 tax for industry will double from $30 \%$ to $60 \%$ of the general $\mathrm{CO} 2$ taxation level.

- Provisions for a CO2-Neutral Public Sector

The public sector is a big consumer and should become a role model in reducing emissions. Such discussions might lead to either a legal framework or to recommendations for the purchasing policy of the public sector. In particular, transport and buildings are set to become focus areas. In Norway, heating of public buildings will be fossil-free from 2018 and purchases of all kinds of vehicles and ferries will be low emitting.

- Investment Funds for the Transition to a CO2-Neutral Society Different models are being discussed for low carbon investements, i.e. the State Pension Fund in Norway.

- The Building Sector

Gradually stricter building codes regarding energy use have been introduced in all the Nordic countries over the years. Recent initiatives from the Nordic Council, such as the Nordic Built Initiative, involve the private sector in particular. This may lead to greater harmonization as well as to higher ambitions, especially with regards to the renovation of existing buildings.

In Norway, all use of heating oil will be banned by 2020, starting already in 2018 for public buildings.

- Transport

The Nordic countries will increase the use of biofuels in the transport sector to reach the EU target of $10 \%$ or above by 2020 . Sweden has further set the target to reach a fossil independent vehicle fleet by 2030. It will necessarily include new measures to stimulate electric cars as well as more sustainable biofuels and efficient vehicles. Further, EU regulation of $\mathrm{CO} 2$ emissions from cars trucks and light 
commercial vehicles will be supported by the Nordic governments. Sweden and Denmark are also considering a kilometer-charge for heavy duty vehicles differentiated after geography.

- Low Carbon Consumption

A political discussion on the impact of consumption on GHG emissions is emerging in the Nordic countries. Though this is still far from concrete policy measures, such a carbon tax on meat, at least the debate has started. 



\section{GHG Projections}

Projections for GHG emission reductions in the Nordic countries are presented in Figure 13, based on official projections from each of the four major countries.

Figure 13: Projection of GHG emission reductions in the Nordic countries in MtCO2e, comprising the baseline with no further initiatives. The projection includes current policies and government targets

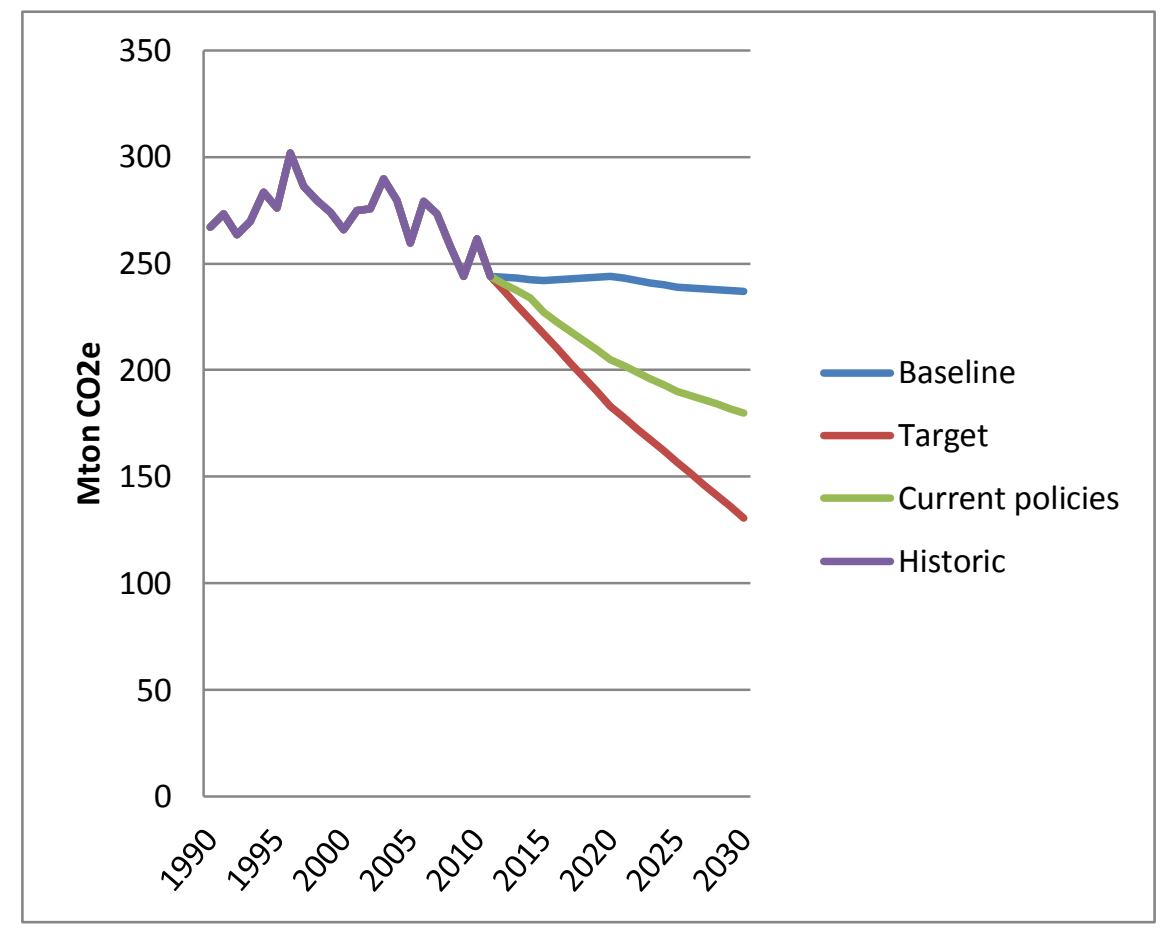

Source: Own calculations based on national GHG emission projections.

If no further policies are applied, GHG emissions are projected to follow the upper (blue) line, more or less remaining at the current level of emissions. This baseline projection includes countries with expected increases in GHG emissions, and others - mainly Sweden and Denmark - with expected emission reductions, even with no further initiatives. It should be mentioned that the baseline scenarios do not necessarily have the same preconditions when it comes to economic growth, carbon price in EU-ETS etc. 
The second (green) line shows the projected emission reduction including already agreed initiatives and policies. In this regard, it should be underlined that the countries may have different criteria to define what constitutes already agreed policies and initiatives, and assessments of the impact of a given initiative is not necessarily made on the basis of the same methodologies. This projection is hence somehow a sum of not fully comparable reduction scenarios from the four largest countries in the region. However, subject to these precautions, the projection shows a substantial reduction of GHG emissions as compared to the baseline scenario.

The third (red) line presents the targets from the Nordic countries as currently decided. This includes the 2020 targets and the agreed vision for 2050 . As it can be seen from the graph, there is a gap in 2020 between the targets and the projected reduction path. The gap increases over the coming decades so fulfilling the targets will require further policies and initiatives.

When looking at the policies and initiatives being implemented and discussed in the Nordic governments, a certain pattern can be observed with regards to the type of measures used in different sectors and towards different target groups.

The first policy choice taken in the Nordic countries is to exploit the renewable sources. Norway and Sweden were early movers on hydropower and Denmark came along when the technologies to use wind power became available. The use of renewable sources is increasing in the entire Nordic region. As examples, Norway and Sweden have a common green electricity certificate system that will ensure 26,4 TWh new renewable electricity production from 2012 to 2020 and establish domestic and international transmission lines. Denmark will further increase the use of wind power. The measures to increase the use of renewables include clear and long-term commitments, investment from the public sector and incentives for the private sector to get involved.

A shift from fossil fuels to renewables is also an important initiative to reduce the gap between targets and the baseline scenario. In the power sector, this is an ongoing initiative in all countries and it has also started in other sectors. In the housing sector, heating will be shifted from fossil to renewable by a mixture of incentives and regulation. As an example, a ban on individual heating oil and incentives to install heatpumps, solar power and wind power will be applied. In the transport sector, taxes and incentives are implemented to shift from fossil fuel-based to zero emission cars. In agriculture and industry, measures mainly include information, research and incentives for use of renewable sources. Support to biogas is an example of this. 
Energy efficiency is a third important way to reduce GHG emissions. In industry, this will be implemented through incentives. Investment funds for transformation to green production and support for R\&D are the main ways to encourage industry to a shift to low carbon production.

In Denmark, a CO2 reduction target for energy suppliers is an efficient measure to make energy suppliers buy the $\mathrm{CO} 2$ reduction and take the lead towards both industry and large housing owners. A higher efficiency in the transport sector is based on taxes and incentives (bonus/malus) to introduce more efficient vehicles. A kilometer tax differentiated by geography is considered in Sweden in order to increase efficiency in freight transport. In Sweden, land use planning and infrastructure planning will also be changed to have an impact on GHG reductions. In several countries, it is on the agenda to let the public sector incorporate GHG reductions in the purchasing policy.

To sum up, the Nordic countries are relatively far when it comes to the use of renewable sources, and this is the major reason for the reductions already achieved. Policy initiatives to further increase the use renewable energy are important to reduce fossil power production and to lessen the gap between targets and baseline scenario. However, the future scope of such initiatives is decreasing as the amount of fossil power production is already being reduced to near zero in the Nordic region.

The major challenge for the coming decade will be the shift from fossil to renewable energy sources in the other sectors too. Here, a mix of economic measures and regulation will be applied. In the building sector, the individual heating with oil will be phased out and building codes to reduce the need for heat will be applied as regulation. In the transport sector, additional $\mathrm{CO}_{2}$ tax is on the agenda in Sweden and in Norway and the incentives to increase the use of zero emission vehicles is expected to remain in place.

Energy efficiency will also be on the agenda, but with less strict regulation. When it comes to industry, agriculture and the transport sector, the measures include funding, R\&D and information. However, in Sweden, the $\mathrm{CO} 2$ tax will be a strong tool also for the future GHG reductions. 



\section{Cases for GHG Reduction Policies}

This chapter presents four cases on how GHG reductions are achieved in the Nordic countries. The intention is to present how a combination of several measures to reduce GHG emissions often work better than isolated measures. The more complex the energy and climate sector becomes, the more packages of measures are required. The four cases are:

- District heating in Sweden.

- Wind power development in Denmark.

- Zero emission vehicles in Norway.

- Low emission cars in the Swedish transport sector.

\subsection{District Heating in Sweden}

\subsubsection{Summary}

District heating has had a major role in reducing GHG emissions in Sweden as well as reducing local pollution in urban areas. Today, district heating accounts for about half of the total heat market in Sweden and is present in every community with more than 10,000 inhabitants.

Since the early 1980s, district heating deliveries have doubled from about $30 \mathrm{TWh}$ to $60 \mathrm{TWh}$ and at the same time the fuel mix has been more or less inverted from about $90 \%$ fossil fuels in 1980 to $90 \%$ nonfossil fuels today.

The main important policy instruments include:

- Local governance, planning and cooperation.

- A non-regulated market environment, stimulating competitiveness and innovation.

- Clear price incentives over time through energy and carbon taxes. 


\subsubsection{Background}

\section{The Technology}

A district heating network is an infrastructure with the potential to use energy in a resource- and cost-efficient manner and to utilize energy that would otherwise have been lost: Excess heat from industries, heat from thermal electricity generation, waste incineration, geothermal heat or low quality bioenergy.

Heating demands can be satisfied with energy of lower temperature, or from "lower quality" energy sources as compared to electricity production. This is why district heating networks have the potential to be very efficient: From a systems perspective, it reduces the demand for primary energy. It is also much easier to control and reduce local emissions from a central heating plant than from individually managed boilers in buildings

Inside houses, a small heat exchanger can replace more bulky and sometimes noisy boilers and provide a high quality indoor climate.

\section{The History}

The first district heating systems were tested already in the late $19^{\text {th }}$ century in the US and Germany. As an example, today's district steam system on Manhattan in New York was commissioned already in 1882. Today, however, modern district heating systems in the US are found primarily on university campuses.

The development of district heating in Sweden began after the Second World War, when rapid growth and urbanisation increased energy demands. Using a district-heating network for heating distribution became an attractive alternative for meeting the challenges of the new era in the emerging cities. Partly thanks to quite strong local governments, without short-term profitability demands, cooperation and planning, district heating systems were established and expanded in many Swedish cities.

It was not until the mid-1960s that the rapid expansion of district heating took off and the real boost came only after the first oil crisis in 1973, when district heating systems could reduce risks by allowing for a variety of energy sources to be used for heating.

The nature of the environmental concerns that have driven of the development of district heating has changed gradually, initially focusing on the reduction of local emissions from individual coal, oil or fuel wood boilers and later becoming part of national climate policy. The air quality of Nordic urban areas has improved tremendously thanks to the introduction of district heating. 


\subsubsection{Development}

\section{District Heating in Sweden Today}

- District heating in Sweden has a total market share of about $50 \%$ of the total market for heating and is still growing.

- Today, this market share corresponds to a heat production of around 60 TWh heat with $40 \%$ from co-generation, producing an additional 10 TWh of electricity.

- Attracts investments of about $€ 0.7$ billion (USD 1 billion) per year.

- District heating systems are present in every community with more than 10,000 inhabitants.

- All together, these systems have about $20,000 \mathrm{~km}$ of district heating pipes.

Due to infrastructure costs and energy losses in less densely populated areas, district heating is best suited for urban areas. The market share of district heating in multifamily houses in Sweden is about $90 \%$ and is likewise very high in public buildings. In individual family houses, the market share is around $17 \%$.

Figure 13: Heat market in Sweden 2009. Source: Swedish Energy Agency 2011

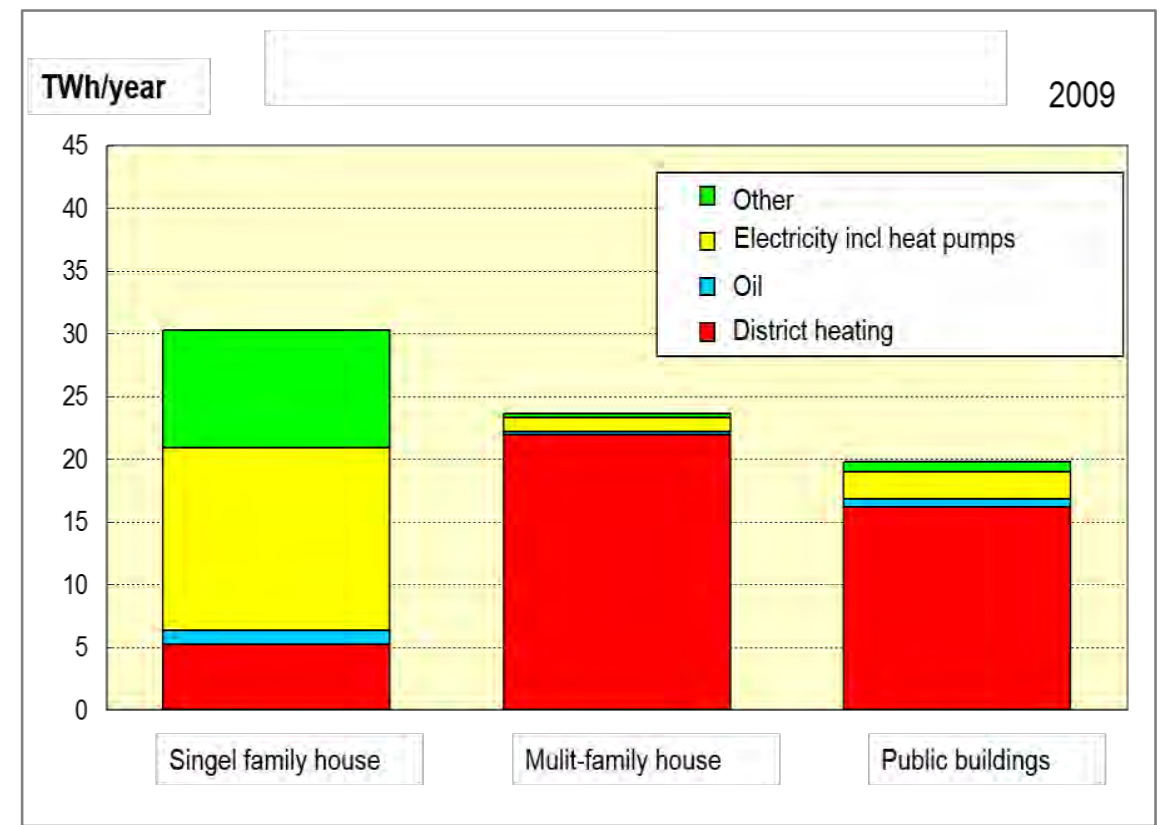




\section{Effects on Climate Change}

Since the early 1980s, district heating deliveries have doubled from about $30 \mathrm{TWh}$ to $60 \mathrm{TWh}$ and at the same time, the fuel mix has more or less been inverted from aroud $90 \%$ fossil fuels in 1980 to $90 \%$ non-fossil fuels today. Today, fossil energy is mainly used for peak load production or a few natural gas combined heat and power plants. For heat production, fossil fuels are gradually phased out of the district heating systems.

This rapid expansion in combination with fossil fuel replacement has made a great contribution to the reduction of GHG emissions in Sweden. Today, emissions from district heating in Sweden are less than $100 \mathrm{~kg} /$ MWh of heat. It should be further noted that many of these emissions stem from household waste that would otherwise have been deposited or incinerated without energy recovery.

\section{Figure 15: Fuels and $\mathrm{CO}_{2}$ emissions in Swedish district heating}

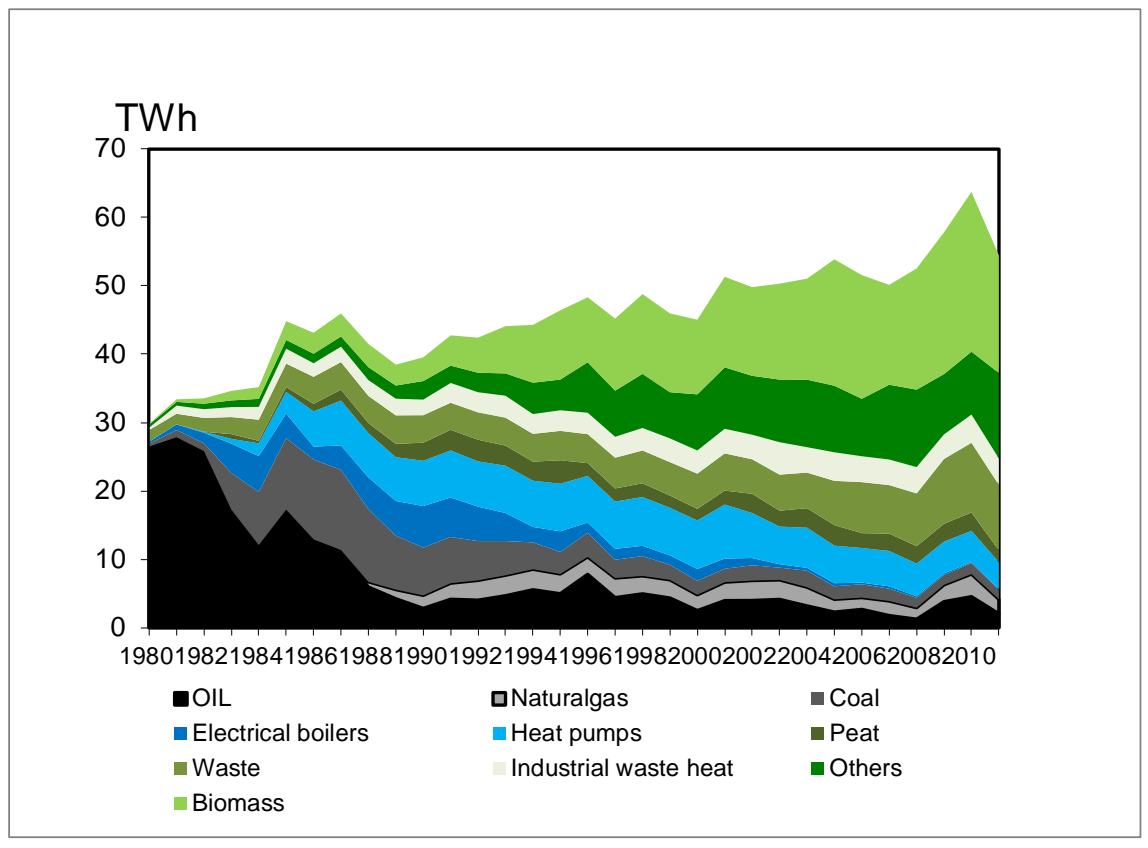

\section{Not only Heating - District Cooling}

A similar technology has been developed for cooling, using a separate infrastructure of pipes for cold water from e.g. the deep ocean or using the heat energy from district heating in cooling machines. District cooling is still quite small in energy terms in Sweden with around 1 TWh of annual deliveries. Stockholm is today the world leading city in district cooling along with Abu Dhabi and Paris. 


\subsubsection{Policy instruments}

\section{Market Environment and Customer Satisfaction}

Even if district heating has received a lot of attention in Sweden, there have been almost no legal regulations developed specifically for district heating systems. They have evolved as part of the broader local planning instruments and the general energy policy instruments, such as taxes and environmental regulations of power plants.

This means that district heating had to prove itself in terms of competitiveness with other heating alternatives. It has expanded due to its capacity to deliver convenient heating and a good indoor climate at competitive prices. This competitive environment has probably been important for innovation and efficiency within the district heating business.

However, once the building is connected to the heat grid, there is usually just one provider of heating in that local network and no competition within the network as compared to electricity grids. This has created a political discussion on how to avoid heat companies benefitting from a dominating position. This is seen to drive a development towards greater transparency in pricing, strengthened consumer rights and increased local competition, though not towards price regulation.

During some periods, national funds have supported climate investments in local communities, which partly have been used to stimulate the extension of district heating grids and the transition to renewable energy. However, the total amount of funds used is small compared with the total annual investments in the district heating industry.

\section{Local Government and Municipality Planning}

Given this largely unregulated environment at national level, well-defined and functional local governance and planning have been important for the development of district heating in Sweden. Many district heating companies are owned by the local community. Even if these companies are profit-driven, their time horizon with regards to return on investments is been longer than would have been the case with private owners. Today, however, the district heating systems in many major Swedish cities are owned by private capital and fully commercial companies.

\section{Energy and Carbon Taxes}

District heating systems are examples of infrastructure with a very long life time, and with the advantage that different heat sources can be used over time. Some power plants are also flexible with regards to the fuels used. This means that, over time, the heat market has been very responsive to changes in energy prices and taxes, later carbon tax. These 
price incentives, in combination with an unregulated market and local innovation and cooperation, have led to today's climate efficient heating systems in Sweden - without the existence of any detailed regulation or heavy subsidies.

The total taxation (CO2 tax and energy tax) of fossil oil for heating in Sweden today is about $€ 0,45$ / litre of which the carbon tax corresponds to about $€ 170 / \mathrm{tCO}_{2}$. This is the highest level of taxation on fossil fuel based energy in the EU and is about to phase out fossil fuels entirely from the Swedish heat market for the household and service sectors. Biofuels are exempted not only from carbon tax but also from the energy tax.

The strong price incentives are effective also for single family houses, which are about to phase out oil as a heat source even in this sector. For such houses, heat pumps, using electricity and sometimes geothermal heat, and wood fuels, have become the two dominating sources of heating.

For some industries, reduced levels of taxation have been applied, which has led to a less aggressive phase-out of fossil fuels for heating in this sector. Such tax reductions are currently in the process of being cut with an aim of being gradually phased out.

\subsubsection{The other nordic countries}

Among the Nordic countries, district heating systems are also widespread in Finland and in Denmark, with comparable market shares to that of Sweden. Iceland has an even greater share of district heating, based on fossil free geothermal heat. In Finland and Denmark, however, the tax incentives to replace fossil fuels have been weaker than in Sweden, which can be seen by a larger proportion of remaining fossil energy used for heating.

Norway has historically had an abundance of hydropower electricity at low prices, which has meant that electricity heating today is widespread and district heating systems not so common. Historically, two cities have had a large district heating system: Oslo and Trondheim. In recent years, new policy measures have come into place to expand district heating, resulting in increasing investments and use.

Tabel 4: District Heating in the Nordic Countries.

\begin{tabular}{llllll}
\hline & Denmark & Finland & Iceland & Norway & Sweden \\
\hline Heat energy delivered (TJ) & 102 & 112 & 25 & 14 & 183 \\
DH market share & $61 \%$ & $50 \%$ & $92 \%$ & $1 \%$ & $48 \%$ \\
Fossil fuels share & $62 \%$ & $79 \%$ & $0 \%$ & $7 \%$ & $10 \%$ \\
Biofuels & $38 \%$ & $11 \%$ & $0 \% 1)$ & $15 \%$ & $40 \%$
\end{tabular}

Source: Euroheat \% Power, fjernvarme.no, biomass and waste, Svensk Fjärrvärme, 100 \% geothermal. 
Looking ahead, it will be increasingly hard for district heating companies to increase their market share further in most of the Nordic countries, given the already high market share in urban areas. Nevertheless, district heating systems form an integrated part of the total energy systems and will continue to develop as such. For example, a stronger link with the future electricity market may develop, with a large share of itermitent renewable electricity production from wind and solar.

\subsubsection{Comments and conclusions}

Different drivers of the development of district heating in Sweden can be identified of which climate policy has only come into play during recent decades. Over time, several motives have been important to different extent during different periods:

- Meeting an increasing demand of urban heating following economic growth and urbanisation.

- A radical improvement of local environments and air quality by phasing out individual boilers in buildings.

- Resource-efficient and cheap heating by utilizing low priced energy resources and residues.

- Reducing climate change by switching from fossil fuels to renewables or waste heat.

- Giving flexibility and reducing future risks by accomodating a variety of energy sources for heating - especially replacing oil after the oil crisis.

District heating has been an important systems solution that has contributed to dramatic reductions of GHG emissions from heating and to increasing the energy security of Sweden. The main important policy instruments include:

- Local governance, planning and cooperation.

- A non-regulated market environment stimulating competitiveness and innovation.

- Clear price incentives over time through energy and carbon taxes.

\section{Heat Market}

Taking a wider perspective, a general use of energy taxation and a stepwise increase of carbon taxes is contributing to phasing out fossil fuels from the heating sector in Sweden. The government anticipates this to happen already before 2020. The use of oil in the household and service 
sectors has already been reduced by $70 \%$ since 1990 and today constitutes only around $8 \%$ of the total energy use in the sector.

The infrastructure of the district heating networks has been important to enabel the heat market to respond to policy incentives and global market changes during the last decade. Individual family houses and buildings outside urban areas have mainly switched from oil to biofuels or heat pumps for heating purposes. The district heating grids seem to hold good potential for continuing the contribution to resource efficient and low carbon heating and cooling services in urban areas.

\subsection{Wind Power in Denmark}

\subsubsection{Summary}

In 2012 wind power accounted for nearly $30 \%$ of electricity production in Denmark and by 2020, it is planned to account for $50 \%$ Windmill production has over the last decades spurred the creation of around 30.000 jobs and a total turnover of 80 billion DKK. The industry is responsible for $10 \%$ of Danish export.

A number of conditions and initiatives are responsible for the development of wind power in Denmark:

- Favourable geographic conditions: A lot of not too strong winds combined with a large sea area with relatively shallow water.

- The creation of a single energy market with clear and favourable framework conditions for wind power.

- Subsidies for renewable energy by means of feed-in-tariffs.

- Transmission lines, both domestic and to neighbouring countries, enabling both import and export of electricity.

- An innovative industry, organizing itself in a cluster, which strengthened it at the level of the international market and facilitated political negotiations.

- Public support to research, development and testing facilities.

\subsubsection{Background}

The two energy crises in the 1970s created a growing concern among the population for finding find alternatives to fossil fuels. The existence of a strong movement against nuclear power since the 1960s meant that 
this was not considered a relevant alternative. Therefore, wind power became an attractive source of energy with strong public support.

Several enthusiasts built their own windmills. At an alternative school (Tvind) in the western part of Denmark, a group of nonprofessionals built a $960 \mathrm{~kW}$ mill already in the 1970s - a proof that wind power worked. One of the early enthusiasts connected the windmill to the electricity net and made the meter run backwards. Soon after, tariffs for selling wind-based electricity were in place.

During the 1970s and 1980s, the national energy plans had increasing focus on wind power, but conservative forces in the power sector warned against it. It was a political issue characterized by strong emotions.

\subsubsection{Results}

Experience from the development of wind power and a wind industry include:

Figure16: Wind power capacity and share of wind power in the domestic electricity distribution

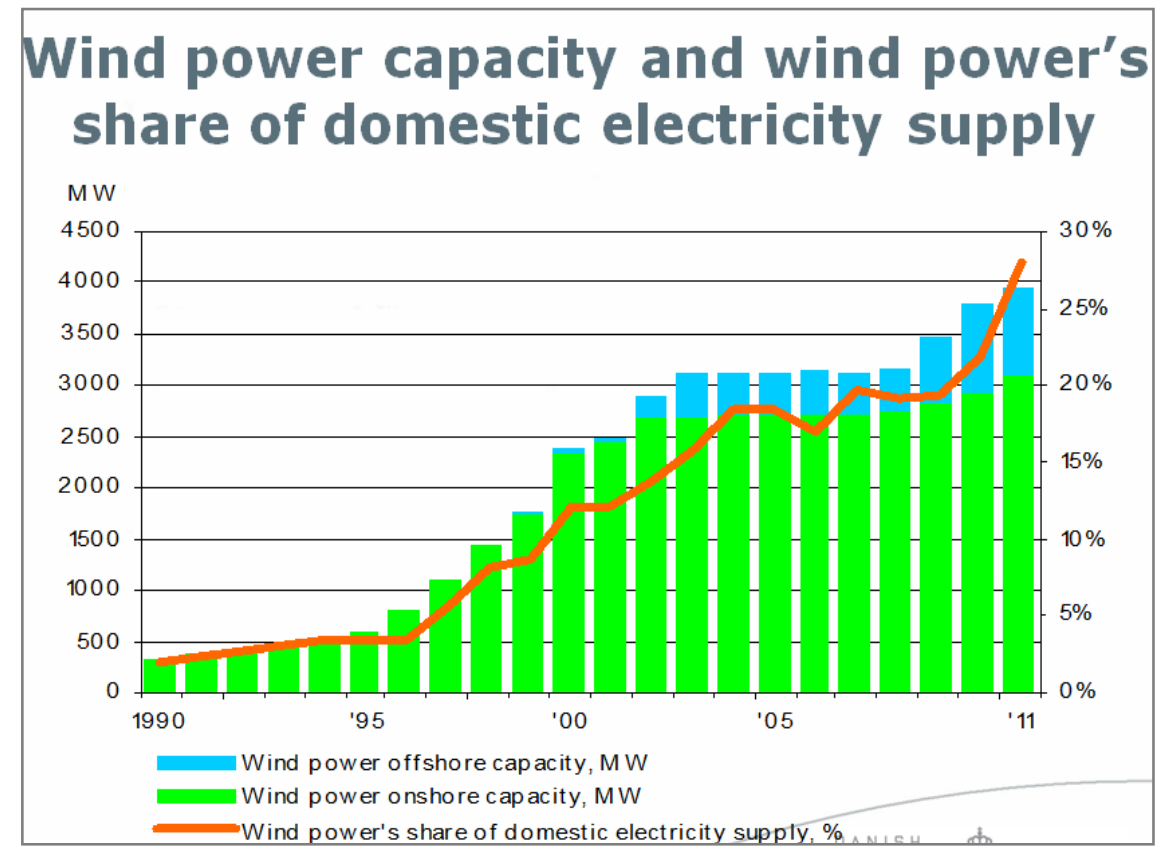

Source: Energistyrelsen.dk

First of all, wind power has become a steadily growing component of the electricity production in the Danish power system. 
In the Energy Agreement settled in 2012, it was decided by almost unanimous agreement in parliament to increase the share of wind power further in the decades to come, both offshore and onshore. The target is to reach a situation in 2020, where wind power supplies $50 \%$ of electricity production in Denmark. Therefore, the same agreement will electrify the Danish energy system, meaning that in the future electricity will play a growing role in the energy supply, i.e. in the transport sector and in heat pumps, eventually making the industry use more electricity than now. This will entail a radical change in the perception of what constitutes climate friendly energy. Up until the 1990s, close to all electricity production in Denmark was based on coal, thus electricity was considered the worst energy source from a climate perspective.

The development of wind power in Denmark has not been without its challenges. There has been resistance to wind turbines "in my back yard". Problems of noise, in particular low frequent noise, was said to make some neighbours to wind turbines ill. Other voices believe that the turbines are a visual harassment to nature. Again, other voices argue that wind power is about the most expensive way to reduce $\mathrm{CO} 2$ emissions. For these reasons, the political support to wind power development has been on and off, depending on the political majority. While conditions for expanding wind power onshore have been favourable since the 1990s, initiatives to build offshore parks have continued to be dependent on the political majority in government.

Alongside the domestic development of wind power, the Danish wind industry has expanded to export markets. Favourable tax deductions in California in the beginning of the 1980s were an important steppingstone for the industry to develop. The industry formed a cluster at a very early stage, which proved to be a clever initiative, as this gave the group of companies a mandate to influence the support schemes for wind power in the Danish government. Furthermore, lobbying for research funding, test facilities and export credits was easier. The industry created new jobs in an export industry. During the last decade, competition from other countries (China) has been growing. 
Figure 8 First figure: Annual turnover in the wind industry (Billion DKK). Second figure: Number of jobs in the wind industry

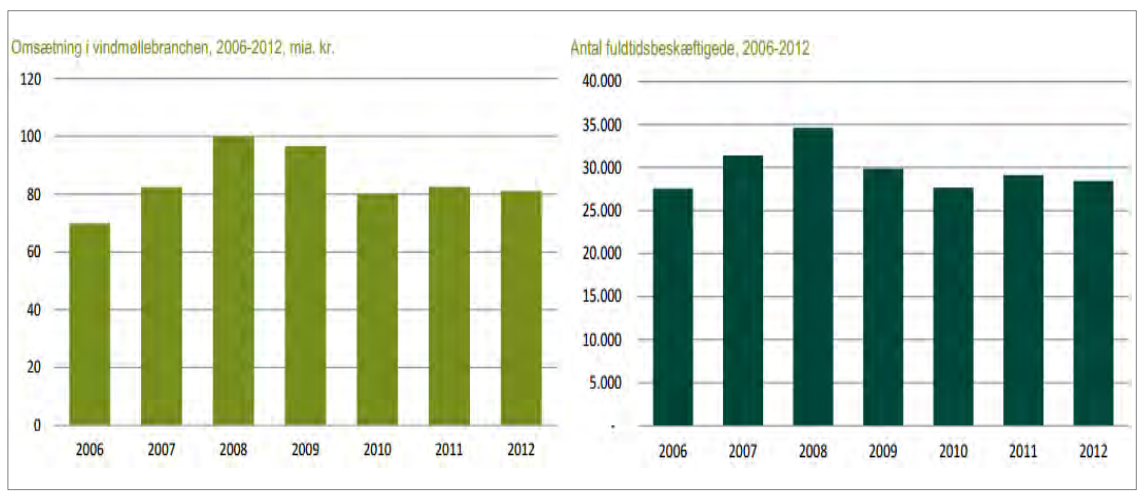

Source: Energistyrelsen.dk

\subsubsection{Policy instruments}

The development of wind power in Denmark can hardly be argued to have been based on a clear policy initiative right from the start. To a certain extent, it was an initiative driven by innovative companies and as such, there was not a clear framework in place for the development. Measures were decided upon, implemented and streamlined along the way. However, a number of principles have supported the wind power development.

\section{Subsidies to Renewable Energy (RE)}

The mechanism has been a fixed price for electricity produced on renewable sources. The price has been defined so that wind power was an attractive investment. The support varies for different types of turbines, but is approximately €0.033/kWh $(0.25 \mathrm{DKK}$ per $\mathrm{kWh})$. For offshore wind, the subsidy is decided after a tender and varies between $€ 0.068$ $/ \mathrm{kWh}$ and $€ 0.14 / \mathrm{kWh}$ (0.51-1.05 DKK per $\mathrm{kWh}$ ). The subsidies for wind power as well as other RE developments are funded by an earmarked tax, (Public Sector Obligation, PSO) on electricity. Onshore turbines have mainly been developed by private investors and the local residents have a right to invest in a share of the total investment. In this way, an incentive to build wind turbines was created. The construction of offshore wind parks are decided by government and tendered out for investment and construction at the lowest price. 


\section{A Uniform Market}

Denmark was divided in two energy markets until 2005, when Energinet.dk was formed as the public owner and developer of the transmission net. This has been important for the distribution of wind power, which is primarily produced in the western part of Denmark and consumed in the eastern part. Rules for trade with electricity between the owners of wind turbines and the net owner were also set by government, favouring the wind power producers.

\section{Transmission Cables - both domestic and to neighbouring countries}

Transmission lines connecting different parts of Denmark have been important for the distribution of electricity on the more windy days. Already now, wind turbines, even on windy days, are capable of meeting the full demand for electricity in Denmark. Furthermore, transmission lines to neighbouring countries are in place. There are already several transmission lines to Norway, Sweden and Germany and more are planned. In the future balancing also through trade with other countries will be essential.

Figure 16: Transmission cables, domestic and to neighbouring contries

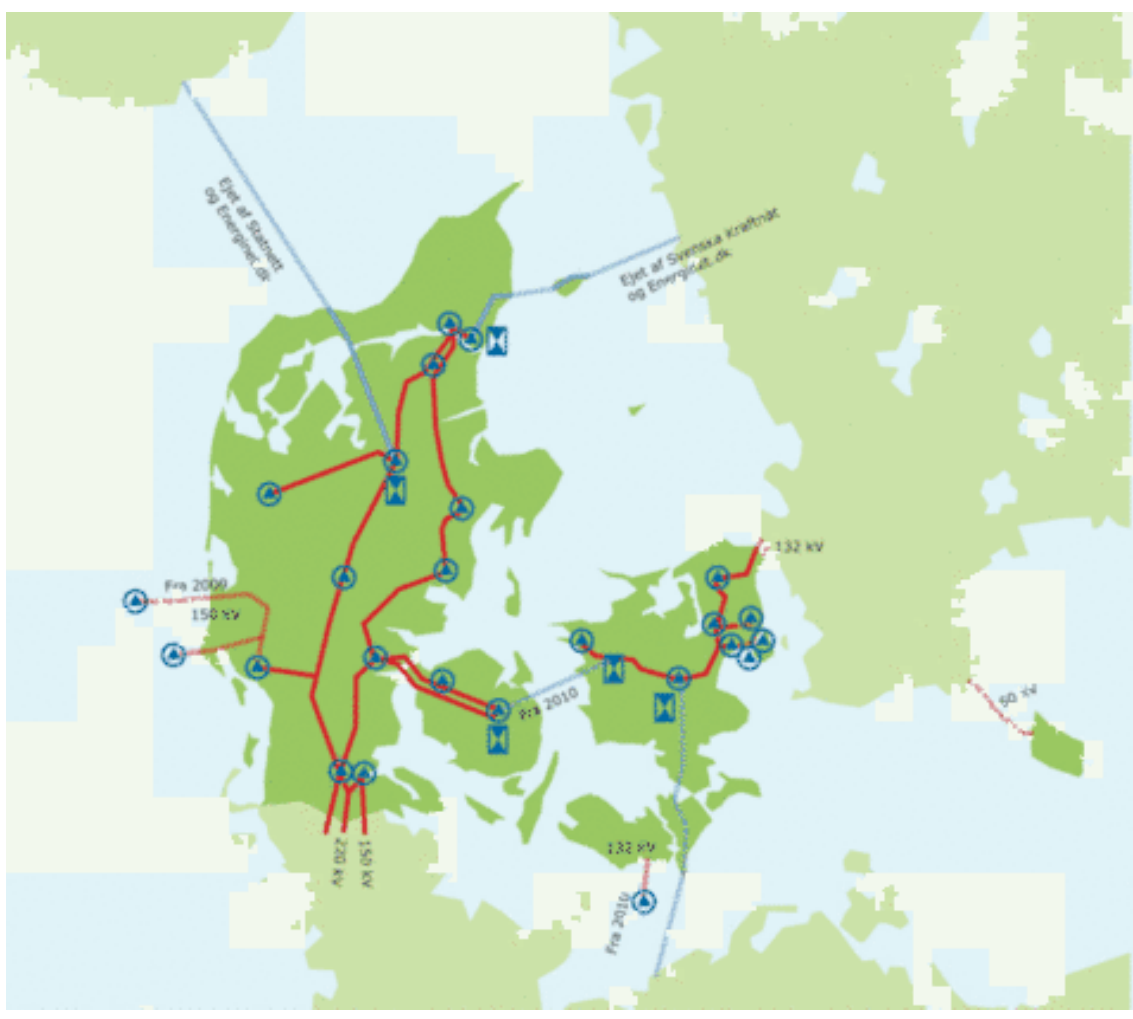

Source: Energinet.dk. 


\section{Support to Research and Development (R\&D)}

The government has supported the ongoing innovation and development of wind turbines by investing in R\&D. Test centres were built and over the last six years close to $€ 40$ million (300 mio. DKK) of public funding have been spent on research in wind power.

\subsubsection{The other nordic countries}

In Norway and Sweden, the development of wind power in scale started much later than in Denmark, benefitting from the technology development and cost reductions done by pioneer countries like Denmark.

In Norway, some early movers started in the 1990s, but the first policy target was set in 2000 as 3 TWh of wind power by 2010. The policy instrument was a direct government investment subsidised by Enova. The target was not reached, but some projects were implemented. Production of wind power in Norway was 1.6 TWh during the last 12 months. ${ }^{15}$

In Sweden, some early development of large-scale wind turbines was done but the industry never took off in the way it did with the more bottom-up-like approach in Denmark. In 2003, a system of certificates for renewable electricity production was launched. Electricity utilities are obliged to buy electricity certficates amounting to the target share, which is increased every year. The cost of the certificates is market based, and incentives constitute the cheapest available alternative. That is why, in the first phase, certificates mainly resulted in an increase of biomass electricity production in CHP (industry or district heating connected).

During the next phase, onshore wind power has become competitive in Sweden. The installed capacity of wind turbines has increased dramatically over the last five years and reached 3,607 MWh at year-end $2012 / 2013$. The production of electricity from wind power has increased by $263 \%$ since 2008 to 7.2 TWh in $2012 .{ }^{16}$ During the first half of 2013, 324.4 MW of wind power were installed. In total, Sweden now has 2,517 turbines with an installed capacity of 3,931 MW.17

From 2012, Norway and Sweden have a common system of green certificates for renewable electricity. The Swedish and Norwigian gov-

\footnotetext{
${ }_{15}$ Aug 2012-july 2013. https://www.ssb.no/energi-og-industri/statistikker/elektrisitet/maaned/2013-0909 ?fane=tabell\&sort=nummer\&tabell $=137175$

16http://webbshop.cm.se/System/TemplateView.aspx?p=En ergimyndigheten\&view=default\&id=314925903 6a042ac9721d7ea77439fbf

17 http://energimyndigheten.se/sv/Statistik/Tillforsel/-Vind/
} 
ernments set the target of renewable electricity to 26.4 TWh for the period 2012-2020. This is a rare example of a cross-border incentive system for renewable energy.

Today, wind power is competing at a plain level field with all other types of renewable electricity production and onshore wind is expected to take the better share of new volumes of renewable electricity during the coming period.

\subsubsection{Comments and conclusion}

Over the last 40 years, a new industry branch has been developed in Denmark, which today accounts for nearly $10 \%$ of Danish exports and is responsible for the creation of many new jobs. Wind power now contributes with $29 \%$ of Danish electricity production. This development has been possible due to an innovative and well-organized industry, conducive, natural conditions and political commitment to both support and develop wind power. The political support comprises a regulatory framework, longterm subsidies and a transmission net.

\subsection{Zero Emission Cars in Norway}

\subsubsection{Summary}

\section{Favourable Market Conditions for Zero Emission Cars}

Through a number of incentives, Norway favours zero emission cars over fossil fuel cars, resulting in Norway having a leading market share of zero emission cars at globally. An all time high record of $9 \%$ rechargeable cars of new cars sales was passed in September 2013.

The incentive system is widely supported by politicians and the public alike. It includes no registration fee, no VAT, free parking, free charging and no road toll, in combination with other important incentives, such as permission to use lanes reserved for public transportation and publicly built charging infrastructure. The main success factors have been:

- Sufficient financial incentives at the time of purchase

- Increased convenience/time saving

- Charging infrastructure

- Long-term reliable policy 
Key learning points from this is if electric vehicles (EVs) are competitive in terms of cost and use, today's EV technology is good enough to compete with fossil fuel cars for a large share of the market.

\subsection{Background}

The first EV enthusiasm and the building of cars in Norway started in the late 1980s. Early in the 1990s, the first important incentives for EV batteries came in place and were gradually improved during the late $1990 \mathrm{~s}$ and early 2000s.

Production of EVs in Norway since 1990 has been an important focus for EV enthusiasm in Norway, and a driver for improved EV incentives. The development of Pivco (later Think) and Kewet (later Buddy) has been challenging for both companies with bankruptcies and halted production during several periods. The production of the Think City, the most well known Norwegian EV brand, was stopped in 2011. Buddy has still production of small EVs from its location in Oslo. Except from some imported EVs from Peugeot and Citroën, the main EVs in Norway until the late 2000s were Norwegian produced.

Figure 19: First EV with own EV signs in the mid-90s were the yellow Kewet, here together with a Nissan Leaf. Pivco, New Buddy, and Think City to the right

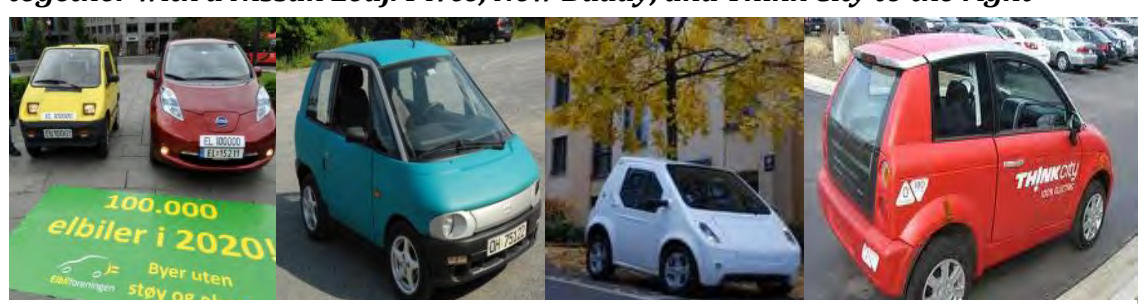

Source: http://www.buddyelectric.no/index.php/om-oss2.

Norway has a high share or renewable electricity production and low electricity prices, which has been an incentive for EVs. However, a political debate on fossil fuel power import from Denmark and a fossil gas power plant in Norway has been raised. 


\subsubsection{Development and results}

The number of EVs in Norway has increased rapidly over the last years. From a level of around 200 cars per year in 2000-2005, to an average of more than 400 in 2006-2009 and more than 2,000 in 2011. In 2011, EVs that resembled normal cars more were introduced, including Mitsubishi i-MiEV, Citroën C-ZERO, Peugeot iOn, and Nissan LEAF. The sale was nearly 5,000 in 2012 and more than 6000 so far in 2013.

Figure 20: Sales of rechargeable cars per year in Norway 2009-2013, specified by car brand. The figure to the right shows the development of car sales in the last months of 2013. This shows a large increase in August and September due to the introduction of the new Tesla $S$ model, coming in addition to the sale of other EV brands, such as the second largest Nissan Leaf

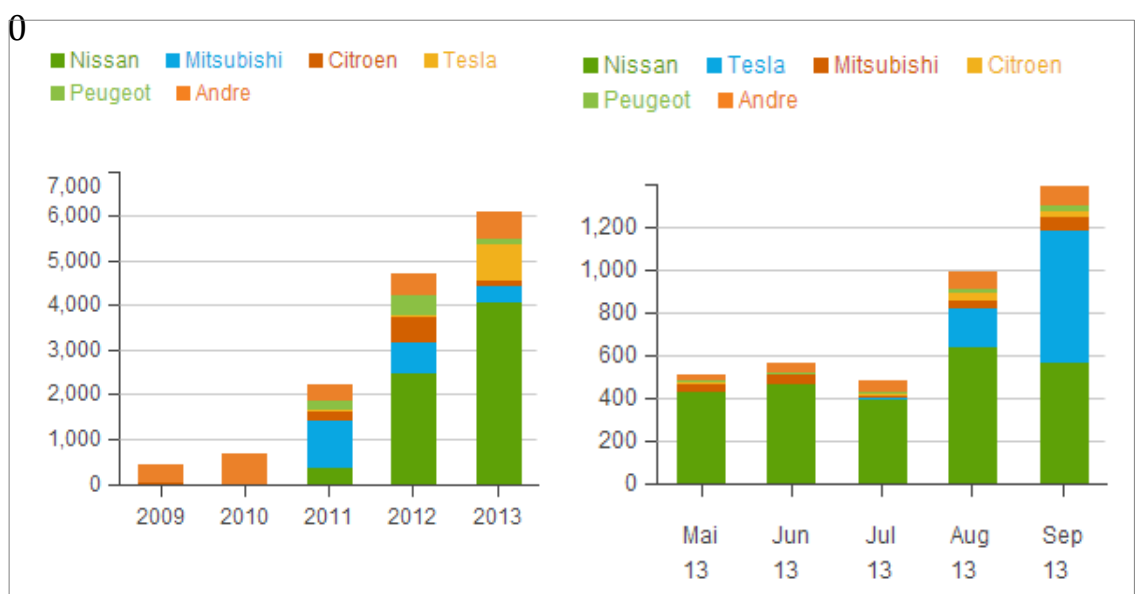

Source: http://www.gronnbil.no/elbiluniverset/kart.ph.

September set a new record with 1388 new rechargeable cars sold (new and import of used cars). This counted for a record high $9 \%$ share of the total sale of new cars. ${ }^{18}$ In 2012, battery EVs and plug-in hybrid EVs amounted to about $3.1 \%$ of sales of new passenger cars, an increase from $1.6 \%$ in 2011.

By the end of September 2013, the amount of EVs in Norway was 15,227 in addition to 623 plug-in hybrids.

18 http://www.gronnbil.no/nyheter/norges-mest-solgte-bil-i-september-er-en-elbil-article352-239.html 
Figure21: The development in number of EVs in Norway within the last 1.5 years

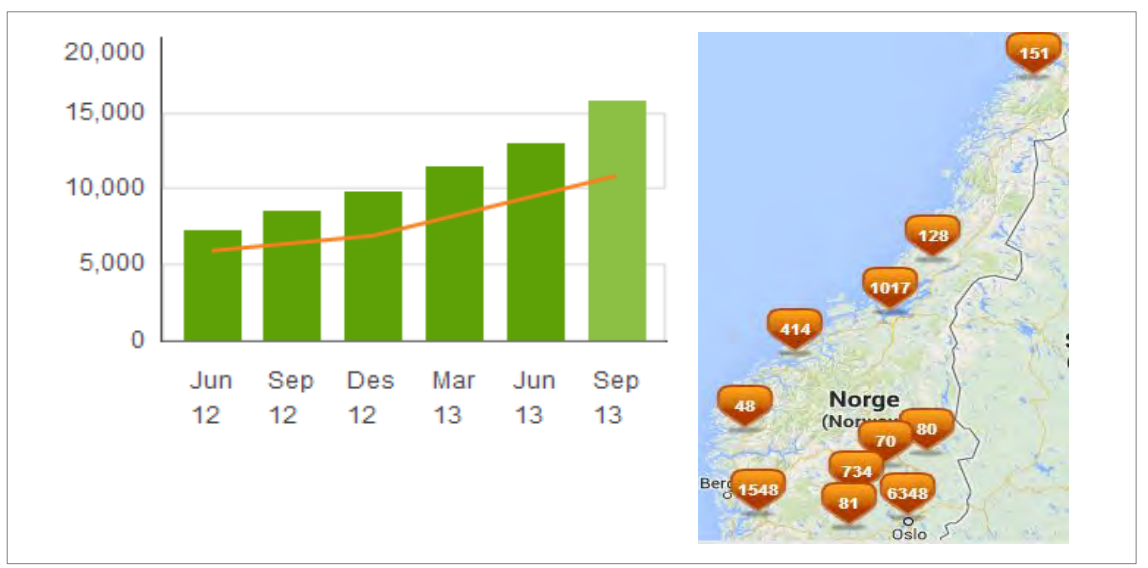

The distribution of electric cars in Norway is mainly in and around Oslo, but also other parts of the country have a high share of EVs. Although the volume is still higher in urban areas than rural areas, the trend shows a significant growth rate in rural areas. The map shows EV distribution per region in Norway as of June 2013. 78 \% of all EVs on Norwegian roads are privately owned while $22 \%$ are owned by business and public authorities (per June 2013).

GHG emissions from road transport in Norway have been at the same level for the last 5 years with a peak in 2007. In 2012, emissions totalled $10.1 \mathrm{Mt}^{19}-19 \%$ of Norway's total GHG emissions. Compared to the total numbers of vehicles in Norway (2.4 million ${ }^{20}$ ), electric cars still represent a small share. Assuming that the EVs replace a car with average emissions, 15,850 electric cars represent approx. 40,000 tonnes CO2 emissions saved per year.

\section{Price}

The price for the most sold EV models in Norway, Nissan Leaf, is approx. $€ 28,500 .{ }^{21}$ The new VW E-UP will be sold at the same price level as Mitsubishi i-MiEV at approx. €23,500.

\footnotetext{
19 http://www.ssb.no/natur-og-miljo/statistikker/klimagassn/aar-forelopige/2013-0507 ?fane=tabell\&sort=nummer\&tabell $=111398$

20 http://www.ssb.no/bilreg/

21231.700 NOK http://www.klimabiler.no/biler/nissan-leaf/
} 


\section{Compared to Other Countries}

The share of electric cars sales in Norway is at world record level. In the first nine months in 2013, it was more than 14 times the average share in Western Europe and more than 4 times the second country on the list in Europe (Netherlands).

Figure 19: Electric car sales

\begin{tabular}{|c|c|c|c|c|c|c|c|c|c|c|}
\hline \multirow[b]{4}{*}{ Market } & \multicolumn{3}{|c|}{ Sep } & \multicolumn{2}{|l|}{ Sep } & \multicolumn{2}{|r|}{ 9-Mths } & \multicolumn{3}{|c|}{ 9-Mths } \\
\hline & Sep & 2013 & Sep & 2012 & $\%$ & 9-Mths & 2013 & 9-Mths & 2012 & $\%$ \\
\hline & 2013 & Electric & 2012 & Electric & Electric & 2013 & Electric & 2012 & Electric & Electric \\
\hline & Electric & Share & Electric & Share & Change & Electric & Share & Electric & Share & Change \\
\hline France & 644 & $0.45 \%$ & 514 & $0.37 \%$ & $25.3 \%$ & 6,318 & $0.48 \%$ & 4,339 & $0.30 \%$ & $45.6 \%$ \\
\hline Norway & 1,044 & $8.58 \%$ & 583 & $5.24 \%$ & $79.1 \%$ & 4,250 & $4.02 \%$ & 2,983 & $2.86 \%$ & $42.5 \%$ \\
\hline Germany* & 556 & $0.22 \%$ & 207 & $0.08 \%$ & $168.6 \%$ & 4,156 & $0.19 \%$ & 2,730 & $0.12 \%$ & $52.2 \%$ \\
\hline United Kingdom & 538 & $0.13 \%$ & 322 & $0.09 \%$ & $67.1 \%$ & 2,538 & $0.14 \%$ & 1,494 & $0.09 \%$ & $69.9 \%$ \\
\hline Nethertands* & 431 & $1.37 \%$ & 368 & $1.15 \%$ & $17.1 \%$ & 2,477 & $0.82 \%$ & 2,800 & $0.66 \%$ & $-11.5 \%$ \\
\hline Sweden & 94 & $0.39 \%$ & 189 & $0.86 \%$ & $-50.3 \%$ & 1,090 & $0.56 \%$ & 603 & $0.30 \%$ & $80.8 \%$ \\
\hline Switzerland & 126 & $0.56 \%$ & 78 & $0.37 \%$ & $61.5 \%$ & 695 & $0.31 \%$ & 621 & $0.25 \%$ & $11.9 \%$ \\
\hline Italy & 69 & $0.06 \%$ & 20 & $0.02 \%$ & $245.0 \%$ & 588 & $0.06 \%$ & 358 & $0.03 \%$ & $64.2 \%$ \\
\hline Spain & 43 & $0.10 \%$ & 16 & $0.05 \%$ & $168.8 \%$ & 433 & $0.08 \%$ & 288 & $0.05 \%$ & $50.3 \%$ \\
\hline Austria & 68 & $0.27 \%$ & 49 & $0.18 \%$ & $38.8 \%$ & 414 & $0.17 \%$ & 309 & $0.12 \%$ & $34.0 \%$ \\
\hline Belgium & 87 & $0.25 \%$ & 36 & $0.11 \%$ & $141.7 \%$ & 352 & $0.09 \%$ & 580 & $0.15 \%$ & $-39.3 \%$ \\
\hline Denmark & 86 & $0.59 \%$ & 44 & $0.32 \%$ & $95.5 \%$ & 331 & $0.24 \%$ & 415 & $0.32 \%$ & $-20.2 \%$ \\
\hline Portugal & 9 & $0.12 \%$ & 5 & $0.08 \%$ & $80.0 \%$ & 126 & $0.16 \%$ & 39 & $0.05 \%$ & $223.1 \%$ \\
\hline Finland & 9 & $0.11 \%$ & 6 & $0.07 \%$ & $50.0 \%$ & 68 & $0.08 \%$ & 88 & $0.10 \%$ & $-22.7 \%$ \\
\hline Eire & 4 & $0.13 \%$ & 3 & $0.12 \%$ & $33.3 \%$ & 40 & $0.06 \%$ & 132 & $0.17 \%$ & $-69.7 \%$ \\
\hline Greece & 0 & $0.00 \%$ & 0 & $0.00 \%$ & - & 0 & $0.00 \%$ & 0 & $0.00 \%$ & . \\
\hline Westem Europe & 3,808 & $0.34 \%$ & 2,440 & $0.23 \%$ & $56.1 \%$ & 23,876 & $0.27 \%$ & 17,779 & $0.20 \%$ & $34.3 \%$ \\
\hline
\end{tabular}

* = Germany 2012 EV sales adjusted as Opel Ampera included, UK 2012 EV sales adjusted as official figures adjusted, Netherlands 2012 revised figure Source: AID/lndustry Sources

Source: http://elbil.no/elbiler/1144-manedsrekord-for-europeisk-elbilsalg

\subsubsection{Policy instruments}

\section{General Government Policy Goal for Zero Emissions Cars}

The Norwegian White Paper (WP) on Climate Policy from 2012 sets the goal to be a leader in infrastructure for EVs and hydrogen cars and the favourable conditions for zero emission cars to be in place by 2020 . The WP goal is an average of 85 grams CO2/km for all new cars sold in 2020 . This is 10 grams lower than the EU goals set for car manufacturers. A broad political consensus in the parliament on this WP and the current financial incentives are ensured at least until 2017, as long as the number of zero emission vehicles does not exceed 50,000. 


\section{Advantages to All Zero Emissions Cars: ${ }^{22}$}

1. Registration Fee Exemption

All zero emission cars are exempt from the registration fee. The exemption has been in place since 1991. Norway has a higher taxation of cars than most other countries. Cars are taxed according to their weight, $\mathrm{CO} 2$ emissions, motor effect and NOx emissions (from 2012). The fee for the most regular models is in the range of $€ 6000$ (NOK 50,000) to €18,785 (NOK 150,000), but low CO2emitting cars pay a lower registration fee than $€ 6000$ (NOK $50,000)$. Full tax relief incentives for zero emissions vehicles therefore provide a larger price incentive than in other countries.

2. Public Parking Fee Exemption

Since the beginning of the 1990s, all zero emission cars have been allowed free parking on public parking spaces.

3. Road Toll Exemption

Road tolls are used frequently in Norway to finance infrastructure such as multiple lane roads, bridges or tunnels and many cities and towns have a toll ring. Fees vary from €1.2 (NOK 10), upon entering a town or city, to $€ 24$ (NOK 200) on some road stretches. All zero emission cars are exempted from such fees. For commuters passing a road toll, the exemptions amount to a considerable sum on a yearly basis. The road toll exemption has been in place since 1996.

4. Free Ferry Transport

All public ferries are free of charge for zero emission cars all across the country.

5. Permission to use Lanes reserved for Public Transportation

Since 2003, zero emission cars have also been permitted to use taxi and bus lanes. This is particularly favourable, as it keeps zero emission cars out of congestion and reduces travel time with up to an hour daily.

6. Road Usage Tax Exemption

The taxation for fossil fuel is divided in two parts: a CO2 tax and a

\footnotetext{
${ }^{22}$ In this document, «zero emission cars» refer to

A) Battery electric cars

B) Fuel cell cars

C) Hydrogen cars with internal combustion engines

With a common term, the first two categories are generally called «electric cars» («el-biler»); they are given the same advantages, whereas cars in category $\mathrm{C}$ are treated somewhat less favourably. However, no mass production of C-category cars are planned in the near future, as opposed to fuel cell cars, which are expected to come on the market around 2014/2015.
} 
road usage tax. The total tax for gasoline is $€ 0.7 / \mathrm{L}$ ( $5.7 \mathrm{NOK} / \mathrm{L}$ ), and road usage part is $€ 0.6 / \mathrm{L}$ (4.8 NOK/L) while diesel is less than total $€ 0.5 / \mathrm{L}$ (4.36 NOK/L) (€0.4/L (3.75 NOK/L) road usage). Hydrogen and electricity for zero emissions cars are exempted from this tax at least until 2017.

\section{Advantages to Electric Cars (battery and fuel cell):}

7. Value-added Tax Exemption on Purchase

In Norway, the purchase of an electric car is exempt from the usual $25 \%$ value-added tax (VAT). Leasing of such cars or purchase of batteries is not exempt, however. The VAT exemption has been in place since 2001.

8. $\quad$ Reduced Tax on Electric Company Cars

Generally, employers cover all car expenses for employees with company cars. However, the employees are liable to taxation. The tax on private use of company cars depends on the age and sales value of the car. In short, employees pay tax from $30 \%$ of car sales value up to $€ 32,606$ (NOK 275,000) and from $20 \%$ of extra sales value. However, employees with electric company cars are given a $50 \%$ tax discount. In 2006, average company car tax expenses for employees were $€ 4150$ (NOK 35,000); electric car tax discount therefore amounted to $€ 2075$ (NOK 17,500).

9. Considerably Lower Annual Fees

An annual fee is levied on all cars registered in Norway. On average, this fee amounts to $€ 349$ (2940 NOK) for passenger cars and €406 (3425 NOK) for passenger cars without a diesel particle filter. For electric cars, the annual fee is limited to $€ 49$ (415 NOK). ${ }^{23}$

\section{Infrastructure}

10. Free Charging Infrastructure

In addition to giving practical and economic advantages, Norway is at the forefront in providing fuel/charging infrastructure for zero emission cars. Authorities spent almost $€ 5.9$ million (50 million NOK) in 2009 and 2010 on supporting the construction of charging stations.

There are about 4000 normal electric charging spots across the country at 1100 charging locations..$^{24}$ Most of these are around the

\footnotetext{
23 http://www.toll.no/templates_TAD/Topic.aspx?id=194976
}

${ }^{24} \mathrm{http}: / /$ www.ladestasjoner.no/ Maps of charging locations 
Oslo area with about 80 fast chargers. ${ }^{25}$ Transnova is supporting new fast chargers in 2013 with $€ 0.7$ million ( 6 million NOK). Tesla has also recently completed building of six large fast chargers stations. ${ }^{26}$ Most of these offer charging for free.

11. Public Charging Spots

Oslo Municipality fulfilled a four years political decision to build 400 normal charging spots at public parking places by 2011 . The political decision is to provide 200 more per year. ${ }^{27}$ All of these offer free parking and free charging.

The municipality also provides financial support of up to 10,000 NOK (max. $60 \%$ of costs) for each installed charging spots like shopping centres, private parking companies, cooperatives, though not by private houses. ${ }^{28}$

12. Hydrogen Filling Stations

Today there are six hydrogen filling stations in Norway built with government support from the research council and Transnova. This includes the filling station for five hydrogen busses operating in Oslo. There are in total approximately 20 hydrogen vehicles in Norway running as test fleets. ${ }^{29}$

13. Transnova

Transnova is the public body assigned with the task of reducing $\mathrm{CO} 2$ emissions from the transport sector.

Transnova was established in 2007 after a proposal from ZERO. Transnova has a budget of about $€ 10.3$ million (NOK 87 million) for 2013.30 The Parliamentary agreement on the Climate Policy White Paper in 2012 has promised to increase this substantially (no exact numbers have been pledged).

14. Public Procurement

Oslo Municipality has decided that all of their service vehicles shall be zero emission vehicles by $2015 .{ }^{31}$ Oslo Municipality is one of the largest car owners/users in Norway with about 1650 cars. Some other municipalities and Government have also started to change their cars to zero emissions solution.

\footnotetext{
25 http://elbil.no/elbilfakta/teknologi/444-hurtigladekartet

${ }^{26} \mathrm{http}: / /$ www.ladestasjoner.no/nyheter/116-30-august-apner-tesla-6-superladestasjoner

$27 \mathrm{http}: / /$ www.ladestasjoner.no/nyheter/107-na-blir-det-400-nye-ladepunkter-i-oslo

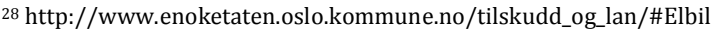

292 Hyundai, 10 mercedes, 2 Think, 2 Mazda and 5 busses (Ruter),

30 http://www.transnova.no/transnova-styrkes

31 http://www.miljo.oslo.kommune.no/transport_og_mobilitet/prosjekter_og_tiltak/article237707-38549.html
} 


\subsubsection{The other nordic countries}

In Denmark, EVs are exempted from registration fee and from annual taxes. A network of charging infrastructure is in place and in some urban areas free parking for EVs is provided.

A large pilot project where several thousand families had a free EV for three months was a great success, and people were enthusiastic about driving the electric cars. However, only 1,300 vehicles have been sold out of a vehicle stock of 2.2 million cars.

This is probably due to the fact that, despite the calculated total cost of ownership is lower for EVs, the investment cost is higher and the risk for first movers of losing the value of the car faster.

\subsection{Low emission cars in Sweden}

\subsubsection{Summary}

Sweden's total emissions from transport increased by $3.6 \%$ between 1990 and 2011. The increase mainly stems from a heavy increase of emissions from heavy duty transport $(+34 \%$ in the period 1990-2011) while emissions from private cars have been reduced by $9 \% .32$

The carbon tax introduced in 1990 is the cornerstone of Sweden's efforts to address carbon emissions. Its effect on transport has been significant, although exact numbers are hard to find. In the overall economy it is however assessed that the carbon tax could be connected to $7 \%$ of total emission reductions.

In addition to the carbon tax, a wide array of policies has been applied, in particular towards private cars. How the share of ethanol driven cars increased but later decreased back to 2006 levels, as well as the increase of diesel driven cars, are both examples that the market responds to policy measures.

\footnotetext{
32 The Swedish Environmental Protection Agency (2013) http://www.naturvardsverket.se/Sa-marmiljon/Statistik-A-0/Vaxthusgaser-utslapp-fran-inrikes-transport
} 


\subsubsection{Background}

According to Sweden's climate targets, emissions in the non-trading sector (not regulated by the EU ETS) must decrease with $40 \%$ (of which $1 / 3$ may be done through offsetting) by 2020, compared to 1990 emissions, which means a reduction of approximately 20 million tons CO2e. Transport makes up half of emissions in the non-trading sector. Hence, the ability to reduce emissions from transport will be crucial for Sweden to reach its target.

In 2011, domestic transport emitted 20 million tons of CO2 (of which $93 \%$ came from road transport). As illustrated in Figure 20, CO2 emissions from the transport sector increased between 1990 and 2005, but has since been reduced by around 1.5 million tonnes. Despite this, in 2011, the CO2 emissions from domestic transport were $3.6 \%$ above the 1990 level (numbers for 2012 are somewhat lower).

Figure 23: GHG emissions from road transportation (in million tons $\left.\mathrm{CO}_{2}\right)^{33}$

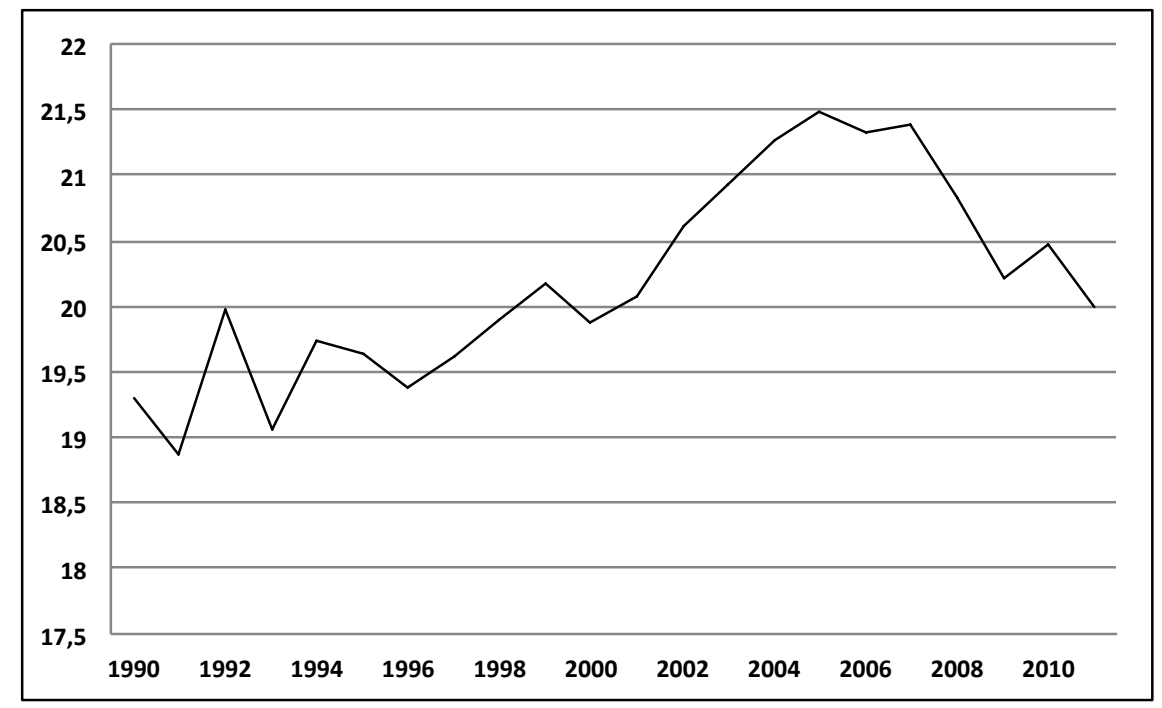

A closer look at the data shows that while the emissions from private cars have been reduced by around $10 \%$, emissions from heavy duty transport have, apart from a dip in 2009, continued to increase. The total increase since 1990 , more than $34 \%$, which can likely be tracked to the increased emissions from heavy duty transports and to an increase in

33 Based on data from The Swedish Environmental Protection Agency 2013 (http://www.naturvardsverket.se/ Sa-mar-miljon/Statistik-A-0/Vaxthusgaser-utslapp-fran-inrikes-transporter/ 2013-10-10) 
the total traffic volume. It is worh noting that a part of the reductions of emissions can be linked to the economic crisis that began in 2008. However, the emissions began decreasing already in 2004 while the traffic volume kept increasing.

Figure 24: GHG emissions from road transportation ${ }^{34}$

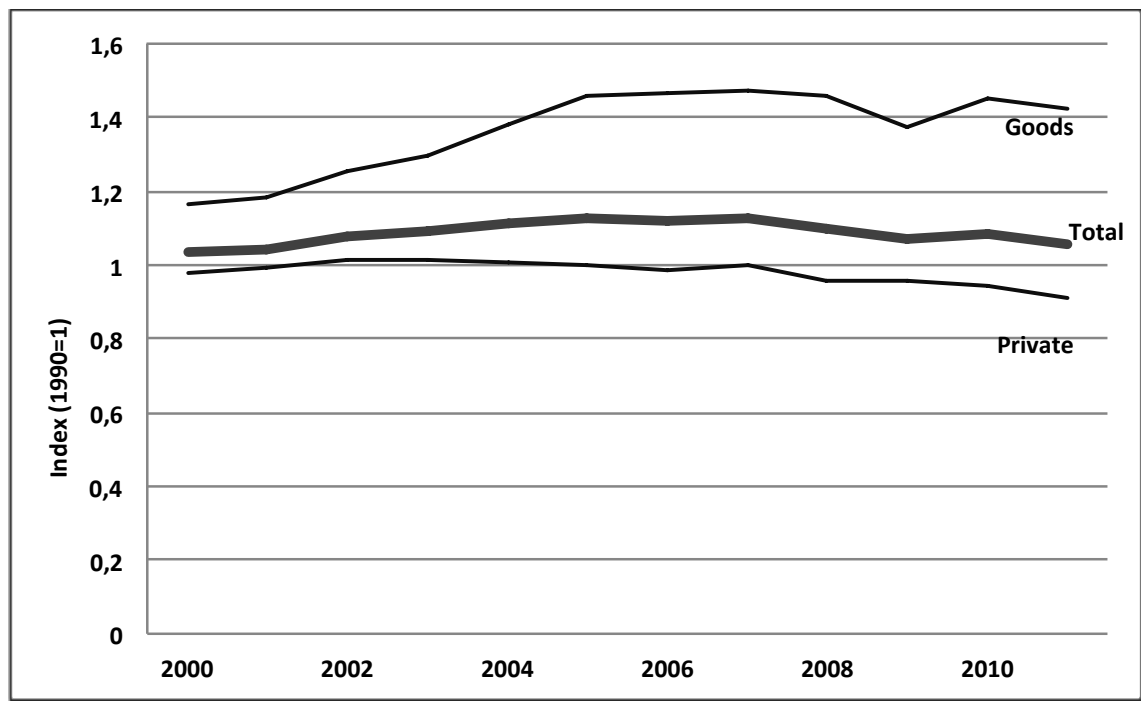

During the last decades, Sweden has used a mix of policy measures to address the problem of emissions from the transport sector. The cornerstone has been the carbon tax introduced in 1991, which has later been complemented by a wide array of directed measures. These will be discussed below.

\subsubsection{Policy insryments}

\section{The Carbon Tax}

The decision to introduce the carbon tax was taken by the Swedish parliament in 1990 and the tax came into force $1^{\text {st }}$ of January 1991 . One of the main underlying factors was the ambition to reduce emissions from the transport sector together with the need for increased revenues.

When introduced in 1991, the carbon tax was set at €0.03/kg 0.25 $\mathrm{SEK} / \mathrm{kg}$ ) and has since then been increased several times. At the moment,

34 Based on data from The Swedish Environmental Protection Agency 2013 (http://www.naturvardsverket.se/ Sa-mar-miljon/Statistik-A-O/Vaxthusgaser-utslapp-fran-inrikes-transporter/ 2013-10-10) 
the carbon tax is €0.12/kg (1.08 SEK/kg C02).35 However, the tax has not been fully imposed on all sectors. The production industry has for example not paid more than around $€ 0.02 / \mathrm{kg}(0.2 \mathrm{SEK} / \mathrm{kg})$ during the entire period. This has been primarily attributed to competitiveness issues.

A carbon tax primarily creates two kinds of incentives to reduce emissions from transport. First, the tax makes it more expensive to drive vehicles that emit $\mathrm{CO} 2$ and thereby creates incentives to reduce emissions and stimulate technological development towards increased fuel efficiency. It also creates the "substitution effect," where demand increases for renewably energy and alternative modes of transportation. The actual outcome of the tax depends on the different adaptation costs and the time horizon that the effect of the tax is evaluated in. Thus, the effect on $\mathrm{CO} 2$ emissions primarily depends on to what extent it actually does influence the behaviour of the people affected by the tax. If people consider the cost of not driving to be too high, they will not change their behaviour.

\section{Other Policies}

In addition to the carbon tax, Sweden has used a variety of policy measures to push a reduction of emissions from transport, many of which have been aimed at increasing the level of renewable fuels.

One example is that all bio-fuelled transportation has an exemption from the energy tax and the $\mathrm{CO} 2$ tax, corresponding to a tax relief of about $€ 0.56 / \mathrm{L}$ ( $5 \mathrm{SEK} / \mathrm{L}$ ) of petrol. This tax relief has been motivated by a goal of reducing the $\mathrm{CO} 2$ emissions and also support the production of alternative fuels in an initial stage.

To increase the availability of renewable fuels, petrol stations exceeding a certain size have been required to offer renewable fuels since 2006 . Stations offering renewable fuels have since then increased from less than 400 to around 1,800.36 To compensate for investment costs in new pumps, the requirement has been complemented by a subsidy.

Another strategy to achieve a more fossil independent vehicle fleet is subsidising R\&D in bio-fuels. This financial support has been increasing

\footnotetext{
35 The Swedish Government (2012): http://www.regeringen.se/content/1/c6/21/43/55/c80041f1.pdf (2013-11-01)

36 Trafikverket (2013); Bilind ex 2012 - Index över nya bilars klimatpåverkan. Trafikverket, Miljö och hälsa, April 2013.
} 
over time and in 2009 a three year support of $€ 98$ million (875 million SEK) was granted. ${ }^{37}$

To further support the development of "cleaner" vehicles, a bonus of $€ 1120$ (10,000 SEK) for newly bought vehicles passing certain environmental requirements was implemented between 2007 and 2009.38 The bonus was available for vehicles considered to be energy efficient (emitting less than $120 \mathrm{~g} \mathrm{CO} 2 / \mathrm{km}$ or using less than $0.5 \mathrm{~L}$ of petrol or $0.45 \mathrm{~L}$ of diesel per 10 kilometre) vehicles using E85 (less than $0.95 \mathrm{~L} / 10 \mathrm{~km}$ ) or biogas (less than $0.97 \mathrm{Nm}^{3} / 10 \mathrm{~km}$ ) as well as electricity or hybrid vehicles. Since July 2009 , this policy has been replaced by an exemption from the vehicle tax for new purchased vehicles passing certain environmental requirements during the first five years. Up until 2013, the tax exemption was awarded to those buying a car emitting less than $120 \mathrm{~g} / \mathrm{km}$. Since 2013, the definition has been changed to take cars' weight into account, creating a more complex system. Since 2013, the tax exemption has also been extended to apply to caravettes, light trucks and busses passing under a certain environmental classification. ${ }^{39}$

The tax exemption has since 2011 been complemented by a "super bonus" for cars emitting less than $50 \mathrm{~g} / \mathrm{km}$. As of the first of the $1^{\text {st }}$ of October 2013, the bonus of $€ 4482$ (40,000 SEK) has been paid to 1,300 buyers of cars emitting less than $50 \mathrm{~g} / \mathrm{km}$.

The number of eco-cars has also increased markedly since the ecocar premium was introduced in 2007 - today every third car sold in Sweden is an eco-car. During the same period, the number of miles driven per car decreased by $6.4 \%$ At the same time, the number of vehicles in Sweden increased by over $22 \%$ or 878,000 vehicles, suggesting that the number of miles driven in total has increased considerably.

Besides these national policies, a number of regional policies such as local congestion charges and free parking have been used to provide incentives to use vehicles emitting less $\mathrm{CO} 2$.

\footnotetext{
37 The Swedish Government (2009): http://www.regeringen.se/content/1/c6/13/97/41/6e1b54c5.pdf\#page=36 38 Idib.

${ }^{39}$ Skatteverket (2013); http://www.skatteverket.se/privat/skatter/biltrafik/

fordonsskatt.4.18e1b10334ebe8bc80003864.html (2013-09-05)
} 


\subsubsection{Evaluation}

In general, the policies implemented have been aimed at improving energy efficiency and/or replacing fossil fuels with renewable fuels. Given the large number of actions, it is hard to evaluate each separate policy. A few general trends on the effects of policies could however be noted, in particular in relation to private transports.

To evaluate the exact impact on emissions from transport is difficult, but studies indicate that the Swedish carbon tax has helped to reduce the overall demand for fossil fuels by approximately $7 \%$ since 1992 and has decreased carbon emissions by around the same amount.

The energy efficiency (number of vehicles multiplied by each vehicle mileage) among private cars has improved. The increase in traffic volume for passenger cars (of about $12 \%$ ) has been compensated for by an increase in emission efficiency (emissions per kilometer). Despite increased emission efficiency, a newly registered car in Sweden emits on average 136 grams of $\mathrm{CO} 2$ per kilometer in 2012, above the EU-average of 132 grams. $^{40}$

Figure 25: CO2 emissions for newly registered cars, gram $\mathrm{CO} 2 / \mathrm{km}^{41}$

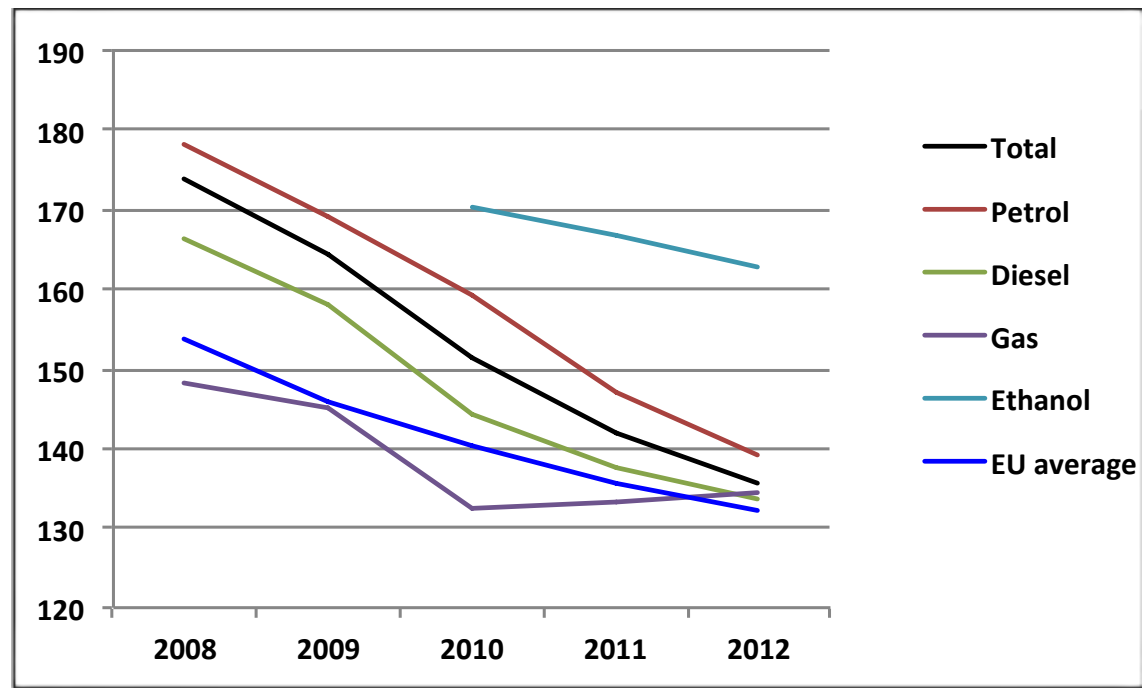

40 The Swedish Transport Agency (2013); http://www.transportstyrelsen.se/sv/Press/Statistik/

Vag/Statistik-over-koldioxidutslapp/Statistik-over-koldioxidutslapp-20111/ (2013-11-01)

${ }^{41}$ Based on data from The Swedish Transport Agency, (http://www.transportstyrelsen.se/sv/

Press/Statistik/Vag/Statistik-over-koldioxidutslapp/ 2013-10-10) 
A development towards a larger share of passenger cars using renewable fuels can be seen, as well as a large increase in the share of diesel fueled cars and a decrease in cars using petrol (see figure below). It is worth noticing that the share of cars driven on ethanol is back at the levels in 2006 after a rapid increase during 2007-2008. It should also be noted that the share of diesel-driven cars has been increasing over the last years. This could partly be explained by the fact that many diesel-driven cars qualified as eco-cars by a slim marginal and were therefore eligible for tax exemption. Also, diesel has benefited from a lower energy tax compared to petrol (in relation to the actual content of energy). To tax diesel and petrol on the same level would mean an increase of about $€ 0.22 / \mathrm{L}$ ( $2 \mathrm{SEK} / \mathrm{L}$ ) on diesel. A stepwise levelling out may be in process, and since 2011 the energy tax on diesel has been raised by €0.04 (0.4 SEK).

Figure 26. Share of newly registered cars by fuel, 2006-2012 (in \%) ${ }^{42}$

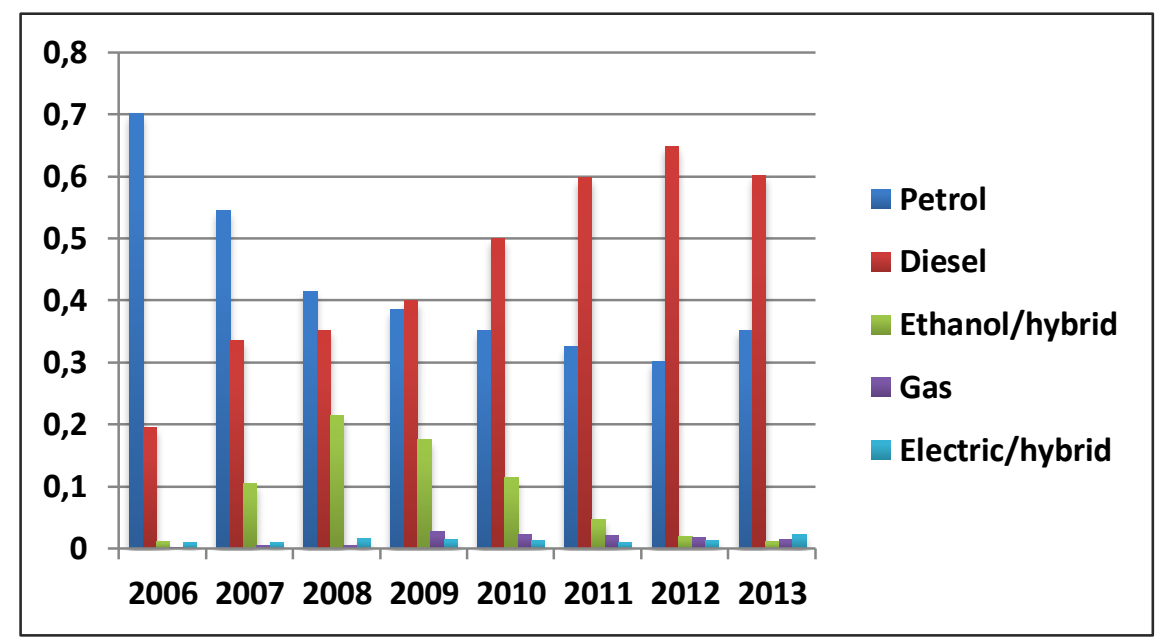

Most of the policies undertaken by the government have been directed towards private cars. It is also here the emission reductions can be seen. To a large extent, the carbon tax and the exemption of the energy tax and the carbon tax on renewables has been the sole policy measures to deal with emissions from heavy transport, where emissions continue to increase. Well aware that emissions from heavy duty transport is a complex

42 Based on data from Statistics Sweden, (http://www.scb.se/Pages/SSD/SSD_SelectVariables_340481. aspx?rxid=f4fc17ef-6d7c-4b5e-b086-d9309e66d706\&px_tableid=ssd_extern\%3APersBilarDrivMedel 2013-10-10) 
issue, it could be argued that the diverging curves of emissions from private cars and goods show that policies have had an impact on emissions.

To find efficient policies to deal with emissions from heavy duty transport remains a challenge for Sweden and for other countries.

\subsubsection{Conclusion}

The carbon tax has likely been one of the major contributing causes of lowering emissions from the transport sector and emissions would likely have increased without it. But the effect has also likely been much stronger as it was combined with other more directed policy instruments, such as subsidies for renewable fuels, incentives to buy cars with less emissions and the requirement for gas stations to offer renewable fuels. These policies have mainly targeted the passanger car sector, which is also where emissions have decreased. There has been less policy targeted towards goods and heavy transports, where emissions have increased.

\subsubsection{The other nordic countries}

Also in Denmark, a reduction in emissions from new cars has been seen. In 2007, a change in the registration fee was implemented favoring low emitting vehicles. A discount for vehicles with low CO2emissions and increased tax for cars emitting more $\mathrm{CO} 2$ has directed the sales of new cars to the market of low emitting cars. However, the price of the cheapest car was reduced at the same time, so the joint effect was higher car sales and reduced emissions from the new car fleet. The average emission is $127 \mathrm{~g} \mathrm{CO} 2 / \mathrm{km}$ for new cars according to the ECE driving cycle.

Taxation for fossil fuels in Norway has been at the same level as in Sweden, but no incentives to increase biofuel use has been implemented. GHG emissions from road transport in Norway increased by 2.3 Mt between 1990 and 2012, where it reached 10.1 Mt. ${ }^{43}$ This corresponds to $19 \%$ of Norway's total emissions. Over the last five years, emissions have been at approximately the same level.

43 http://www.ssb.no/natur-og-miljo/statistikker/klimagassn/aar-forelopige/2013-05-

07 ?fane=tabell $\&$ sort=nummer $\&$ tabell $=111398$ 
Changes in the registration fee system over the last years have been a driver towards less CO2 emissions per km. In September 2013, the average emissions for petrol cars were $127 \mathrm{~g} / \mathrm{km}$ and $134 \mathrm{~g} / \mathrm{km}$ for diesel cars. ${ }^{44}$ The total average was $118 \mathrm{~g} / \mathrm{km}$, brought down by a $9 \%$ share of electric vehicles.

${ }^{44}$ http://ofvas.no/co2_utslippet_1/co2_utslippet_2013/co2_utslippet_i_september/ 


\section{Sources}

UNFCCC National Inventory Submissions 2013

UNFCC

WORLD BANK

EEA

International Energy Agency (2013)

Nordic energy

Svenskenergi

Fjernvarme

Biomass and Waste

Energistyrelsen

Statistikbanken

Opplysningsrådet for Veitrafikken

\section{Webpage}

http://www.ens.dk/sites/ens.dk/files/dokumenter/publikationer/downloads/accel erating_green_energy_towards_2020.pdf

http://www.miljodirektoratet.no/klimakur/

http://ec.europa.eu/energy/observatory/oil/bulletin_en.htm

http://fjernvarme.no/uploads/fjernvarmeprm20131003.pdf

https://www.ssb.no/energi-og-industri/statistikker/elektrisitet/maaned/2013-0909?fane=tabell\&sort=nummer\&tabell=137175 Aug 2012-july 2013.

http://webbshop.cm.se/System/TemplateView.aspx?p=Energimyndigheten\&view= default\&id=3149259036a042ac9721d7ea77439fbf

http://energimyndigheten.se/sv/Statistik/Tillforsel/-Vind/

http://www.buddyelectric.no/index.php/om-oss2,

http://www.gronnbil.no/elbiluniverset/kart.ph

http://www.gronnbil.no/nyheter/norges-mest-solgte-bil-i-september-er-en-elbilarticle352-239.html

http://www.ssb.no/natur-og-miljo/statistikker/klimagassn/aar-forelopige/201305-07?fane=tabell\&sort=nummer\&tabell $=111398$

http://www.ssb.no/bilreg/

http://www.klimabiler.no/biler/nissan-leaf/

http://www.elbil.no/elbiler/734-internasjonale-salgstall-for-elbil

http://www.toll.no/templates_TAD/Topic.aspx?id=194976

http://www.ladestasjoner.no/

http://elbil.no/elbilfakta/teknologi/444-hurtigladekartet

http://www.ladestasjoner.no/nyheter/116-30-august-apner-tesla-6superladestasjoner

http://www.ladestasjoner.no/nyheter/107-na-blir-det-400-nye-ladepunkter-i-oslo 
http://www.enoketaten.oslo.kommune.no/tilskudd_og_lan/\#Elbil

http://www.transnova.no/transnova-styrkes

http://www.ssb.no/natur-og-miljo/statistikker/klimagassn/aar-forelopige/2013-

05-07?fane=tabell\&sort=nummer\&tabell $=111398$

http://ofvas.no/co2_utslippet_1/co2_utslippet_2013/co2_utslippet_i_september/

http://www.miljo.oslo.kommune.no/transport_og_mobilitet/prosjekter_og_tiltak/ar ticle237707-38549.html

https://notendur.hi.is/ thorstur/teaching/UAU106/2012_HugiO_Climate.pdf http://www.naturvardsverket.se/Sa-mar-miljon/Statistik-A-O/Vaxthusgaserutslapp-fran-inrikes-transporter/_2013-10-10

http://www.naturvardsverket.se/Sa-mar-miljon/Statistik-A-O/Vaxthusgaserutslapp-fran-inrikes-transporter/ 2013-10-10

http://www.transportstyrelsen.se/sv/Press/Statistik/Vag/Statistik-over-

koldioxidutslapp/ 2013-10-10

http://www.scb.se/Pages/SSD/SSD_SelectVariables__340481.aspx?rxid=f4fc17ef

-6d7c-4b5e-b0869309e66d706\&px_tableid=ssd_extern\%3APersBilarDrivMedel

2013-10-10 
Nordic Council of Ministers

Ved Stranden 18

DK-1061 Copenhagen K

www.norden.org

\section{Nordic Climate Policy}

The Nordic countries are often seen as green both in terms of a good environment and being capable of reducing greenhouse gas (GHG) emissions. This report is concerned with the development in GHG emissions over time and with the policies that have been effective in the reduction path. The purpose of the description is both to highlight effective climate policies and to tell the comprehensive story of climate policy in the Nordic countries. The project is developed in partnership with the Open Climate Network, an international network lead by the World Resources Institute.

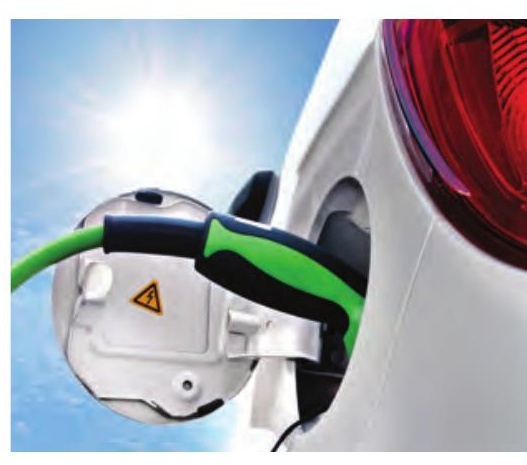

